\title{
The Sub Prime Crisis: Implications for Emerging Markets ${ }^{1}$
}

\author{
William B. Gwinner, Lead Housing Finance Specialist, The World Bank \\ Anthony Sanders, Professor of Finance and Real Estate at the W.P. Carey College of \\ Business of Arizona State University
}

This paper-a product of the Global Capital Markets Non- Bank Financial Institutions Division, Financial and PrivateSector Development Vice Presidency-is part of a larger effort in the department to promote stable and accessible housing finance systems in developing countries. Policy Research Working Papers are also posted on the Web at http://econ. worldbank.org.

The author may be contacted at wgwinner@worldbank.org.

\begin{abstract}
This paper discusses some of the key characteristics of the U.S. subprime mortgage boom and bust, contrasts them with characteristics of emerging mortgage markets, and makes recommendations for emerging market policy makers. The crisis has raised questions in the minds of many as to the wisdom of extending mortgage lending to low and moderate income households. It is important to note, however, that prior to the growth of subprime lending in the 1990s, U.S. mortgage markets already reached low and moderate-income households without taking large risks or suffering large losses. In contrast, in most emerging markets, mortgage finance is a luxury good, restricted to upper income households. As policy makers in emerging market seek to move lenders down market, they should adopt policies that include a variety of financing methods and should allow for rental or purchase as a function of the financial capacity of the household. Securitization remains a useful tool when developed in the context of well-aligned incentives and oversight. It is possible to extend mortgage lending down market without repeating the mistakes of the subprime boom and bust.
\end{abstract}




\section{Note to the reader:}

Endnotes are printed as a separate Pdf document (See Gwinner-Sanders endnotes). With an e-article, this solution facilitates the access to references by avoiding the constant scrolling back and forth between text and footnotes. The reader can open both the article and the endnotes and then switch back and forth with ALT+Tab.

The editor

\section{Table of Contents}

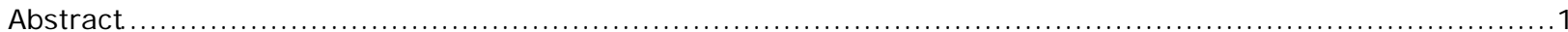

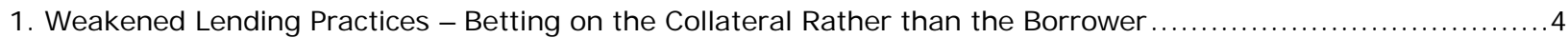

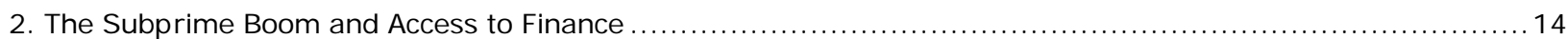

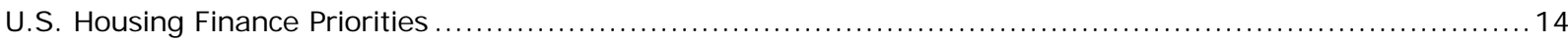

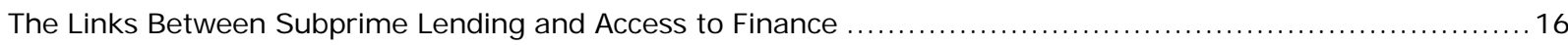

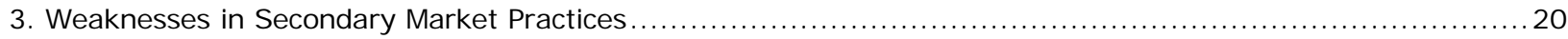

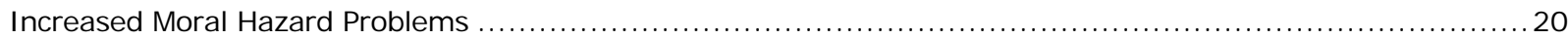

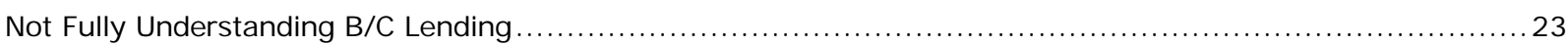

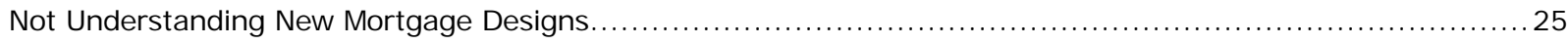

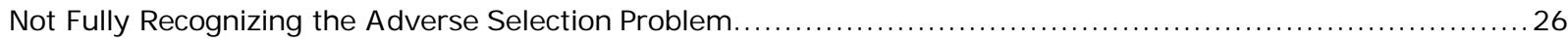

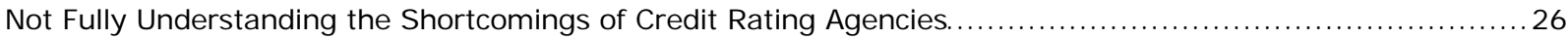

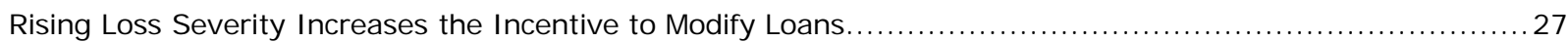

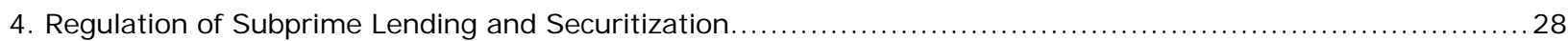

Page 2 
The Importance of Systemic Effects.....

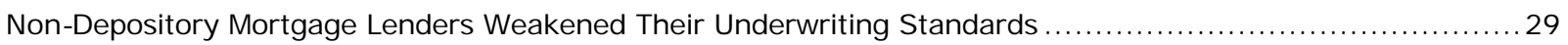

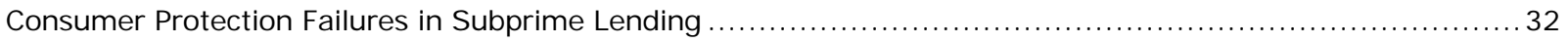

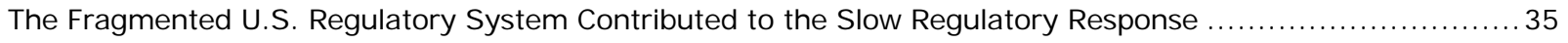

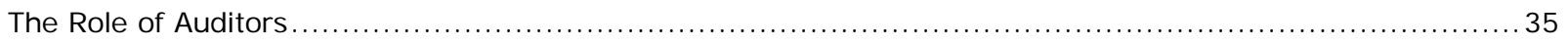

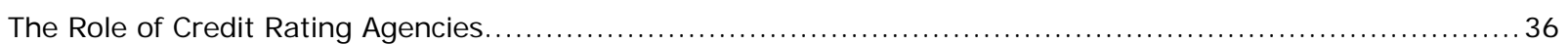

Basel II Capital Accords Would Have a Limited Effect on the Subprime Boom and Crisis....................... 36

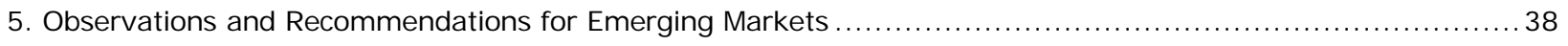

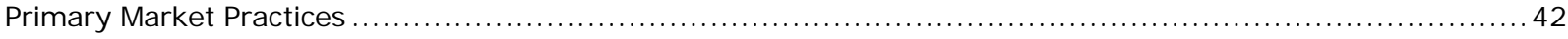

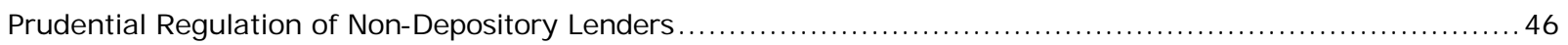

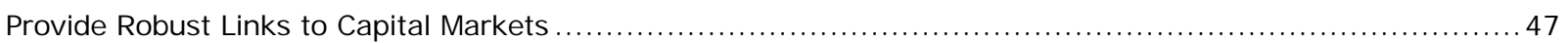

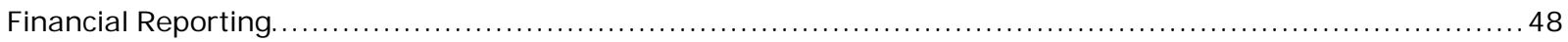

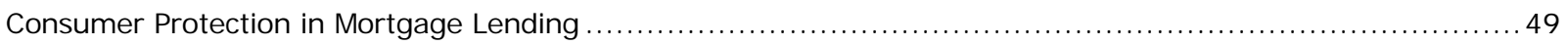

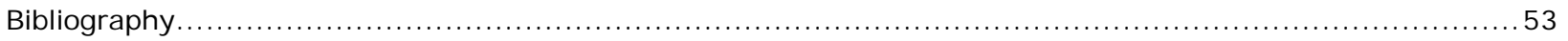




\section{Weakened Lending Practices - Betting on the Collateral Rather than the Borrower}

Ten years of ballooning property prices led to excessive optimism by investors and lenders. In the U.S., depending on the index employed, national average house prices rose between 53 and 86 percent between the mid-1990s and 2006. ${ }^{2}$ At the same time, mortgage originations rose by five times, peaking at $\$ 3.9$ trillion in 2003 (Chart 1). Markets such as Los Angeles and New York have strongly outperformed the national average and many other cities. National indexes for real rents and house prices largely moved together until 2000, when they diverged, and real house prices moved to a level 70 percent higher than that of real rents. Later, as the property balloon deflated in 2006 and 2007, rising subprime defaults spurred a reevaluation of credit spreads and credit market conditions that reflected broader and more fundamental issues. ${ }^{3}$ Apparently, individuals viewed real estate as a foolproof investment opportunity until they decided that it was not, at which point prices began to decline (André, et al., 2006, Shiller, 2007). 
Chart 1: House prices and mortgage originations

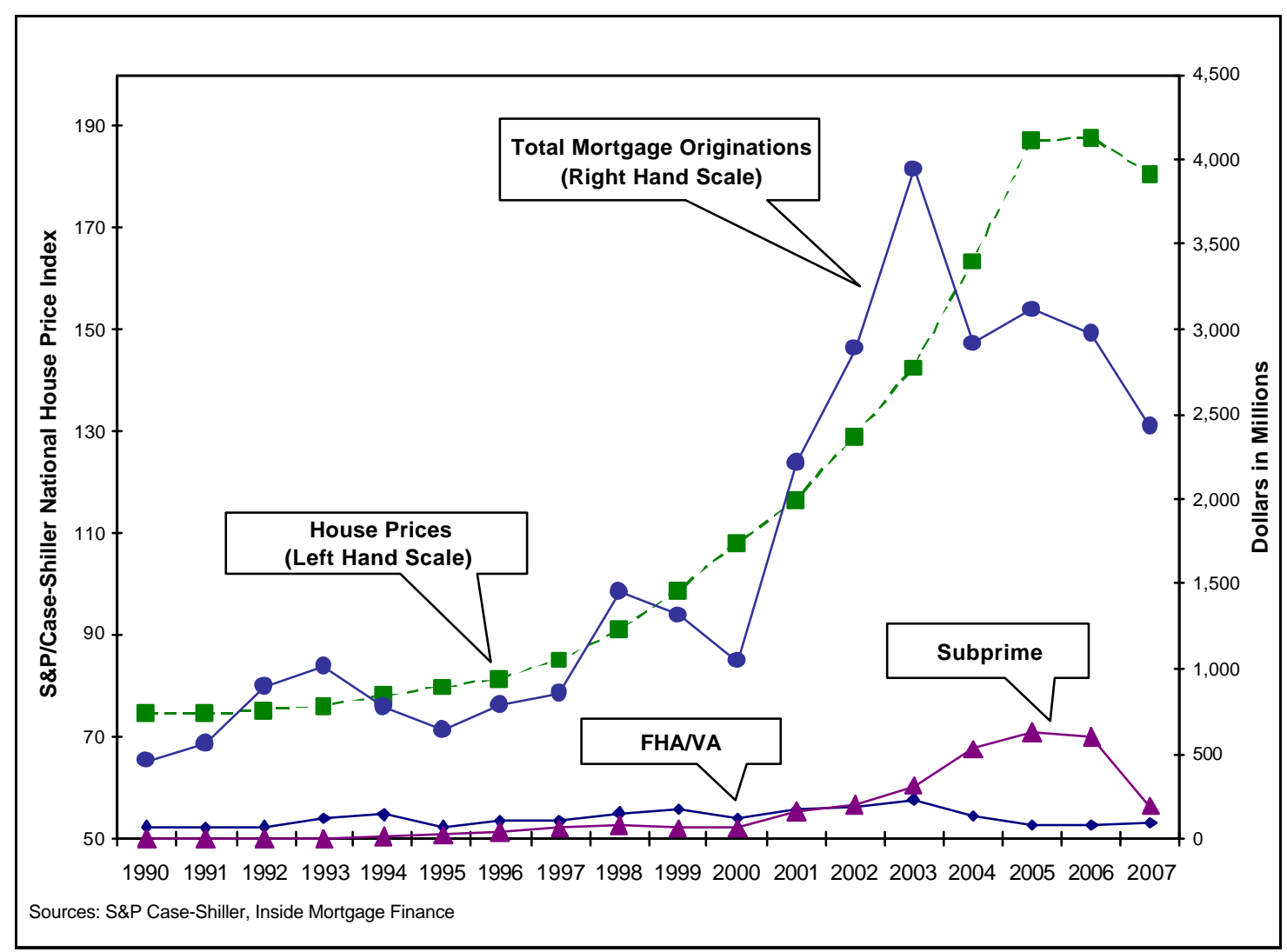

Subprime lending drove house price increases in some areas. Banks and investors act procyclically, extending credit more aggressively and competing for market share as collateral prices rise, when lending decisions seem less risky. Real estate cycles are lengthened by investor optimism during a boom and pessimism following its exhaustion. The current credit crunch is emblematic, with liquidity drying up and spreads widening dramatically on high quality prime mortgage-backed paper even though it continues to perform well. Booming real estate lending carries accelerator effects, and its cessation in a bust contributes to a more rapid slow down. Mian and Sufi (2008) show that mortgage credit underwriting standards were relaxed from 2001 to 2005 in zip codes with large numbers of high risk borrowers and negative relative income and employment growth. 
Relaxed standards were associated with increased mortgage lending, rising house prices, and a subsequent increase in defaults.

\section{Disaster myopia in sub-prime lending manifested itself in weakened underw riting standards, aggressive investor bids for above-market security yields, and an absence of investor vetting of the collateral behind the} securities ${ }^{4}$ As the U.S. real estate boom progressed during the 1990s, home buyers and bankers forgot the downturn of 1989 and 1990, and real estate crises in other countries. More investors were attracted to residential real estate - the percent of mortgages issued for non-owner-occupied homes rose to 15 percent in 2004 from the historically normal 5 percent (Morgan Stanley, 2005). In addition, lending to more risky borrowers grew, as subprime lending took off. ${ }^{5}$

\section{Subprime ARMs seriously underperform other loan types (Chart 2). Serious} delinquencies ( 90 days or more delinquent or in foreclosure) for all subprime loans fell from 2002 to the end of 2005, and then almost tripled, rising from 5.68 percent at third quarter 2005 to 14.44 percent at the end of 2007. In the same period, serious delinquencies for subprime ARMs quadrupled, from 5.15 percent to 20.43 percent. Prime fixed rate delinquencies remained stable at less than 1 percent until the end of 2006, and then rose to 1.67 percent at the end of 2007, perhaps reflecting the effects of house price declines on high loan-to-value (LTV) lending. Serious delinquencies for FHA-insured loans have risen, but to the same degree as subprime. Serious delinquencies of all FHA loans rose from 5.4 percent in the third quarter of 2005 to 6 percent at the end of 2007 . Serious delinquencies for FHA ARMs almost doubled in the same period, from 4.87 percent to 8.72 percent, but remain well below the level of subprime ARMs. 
Chart 2: Serious delinquencies: FHA outperforms subprime loans

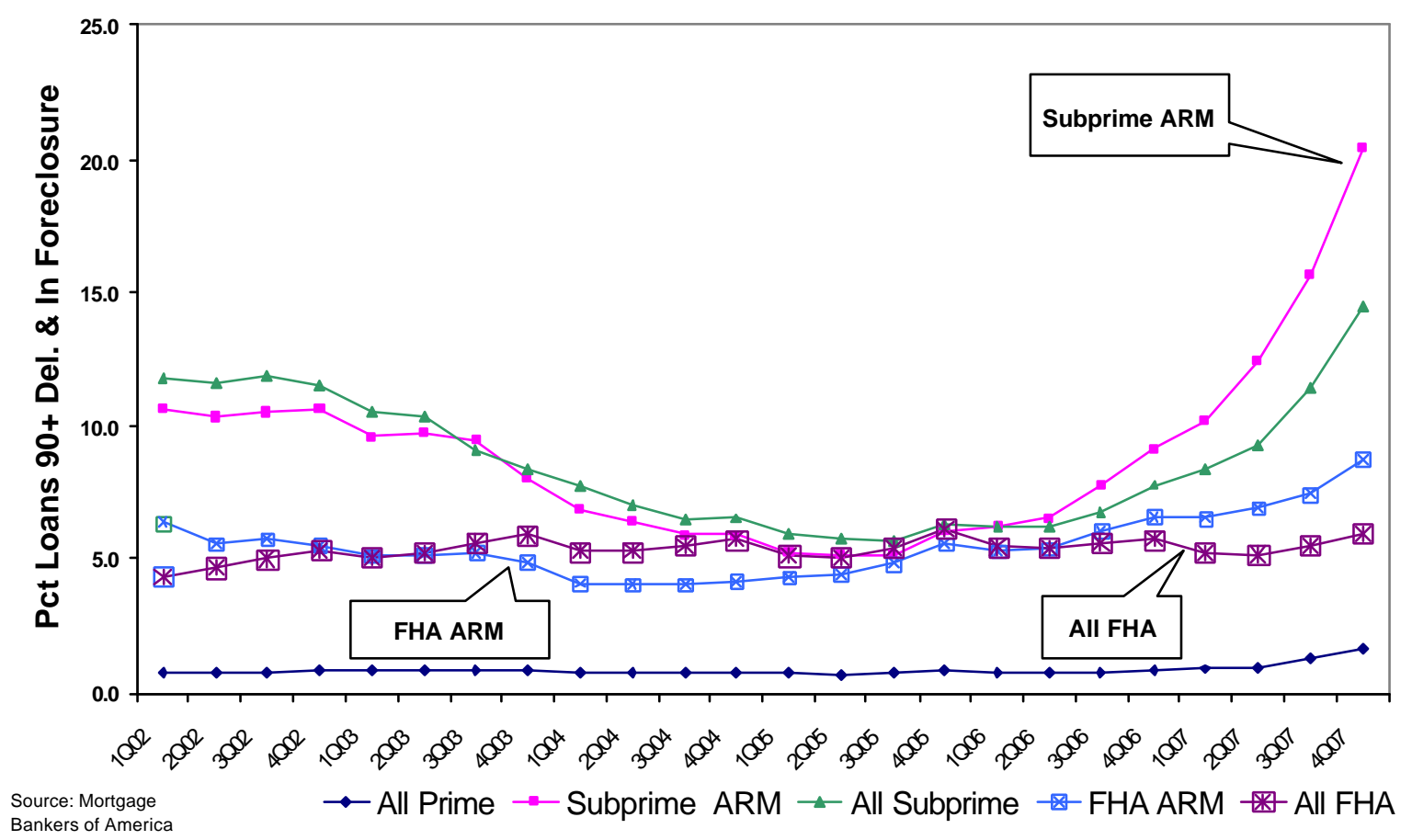

The primary cause of subprime ARM defaults has been weak underwriting, in large part by non-bank lenders. Between 40 and 50 percent of subprime loans were made by independent non-bank lenders between 2004 and 2006 (Avery, et al 2007). Non-bank lenders such as New Century Financial aggressively pursued the "originate to distribute business model," where it originated loans for sale to the capital markets. Founded in 1995, by the end of 2006 New Century was the third largest subprime lender in the country, with loan production that year of $\$ 51.6$ billion. New Century filed for bankruptcy protection in April, 2007, primarily as a result of insufficient capital to satisfy demands from investors to repurchase defaulted and deficient mortgages. According to the bankruptcy court examiner, New Century had a "brazen obsession with increasing loan originations without due regard to the risks associated with that business strategy." The primary consideration for loan quality was the ability to sell in the secondary market. More than 70 percent of loans originated by the company had low initial teaser 
rates, and 40 percent were underwritten on a stated income basis. New Century made frequent exceptions to its underwriting guidelines for borrowers who might not otherwise qualify for a loan. Early payment defaults, a sure sign of weak underwriting, rose from 4.38 percent of loans made in 2003 to 13.1 percent of loans in early $2007 .{ }^{6}$ (Missal, 2008).

Alternative mortgage designs can be dangerous to the financial system. Subprime borrowers, those with poor credit records, a history of bankruptcy, or who are overextended on their credit, often selected mortgage products that are not typical of prime borrowers that have stronger credit records. Prime borrowers typically choose standard, long-term, fixed-rate, mortgages and make a down payment of 20 percent or more. Historically, roughly 80 percent of prime originations have been fixed rate in any given year, and about 20 percent have been ARMs. Subprime borrowers often made low down payments (between zero and 10 percent) and chose riskier loan products, including:

- "option" mortgages, which allow borrowers to defer some of their payments but which also result in increasing loan balances, also known as negative amortization mortgages,

- "convertible" mortgages, which start with fixed rates, then convert to adjustable rates at a pre-specified reset date,

- "low documentation / no documentation" mortgages, where the borrower provides no or minimal documentation on employment, income, etc.

Given the recent failure of IndyMac, an Alt-A lender in Southern California, increased attention is likely to be given to Alt-A, no documentation or low documentation lending since these are inherently risky and susceptible to downturns in national and local housing markets. ${ }^{7}$

So far, neither subprime ARM “teaser" interest rates nor subsequent rate adjustments appear to have been a primary driver of defaults. One of the more risky products during the subprime boom has been hybrid ARMs that feature an initial fixed teaser rate for two or three years, and that then adjust to a variable rate that is 
linked to a capital market benchmark such as the one year Treasury bill, with a spread. As these loans feature thirty year amortization schedules, they are known as $2 / 28$ or $3 / 27$ loans. Foote, et al (2008) show that the initial teaser rate on 2/28 ARMs averaged from 7.3 percent in 2004 to 8.6 percent in 2007, with an average spread of about 3 percent over the one year prime ARM rate. The fully-indexed rate fell from 11.5 percent in 2004 to 9.1 percent in 2007. The bulk of subprime ARMs were expected to reset in 2007 and 2008. (Center for Responsible Lending 2008). Interest rate cuts by the Federal Reserve in 2008 have muted to some extent the effects of this wave of adjustments. Demyanyk and Van Hemert (2007) show that most subprime ARM defaults have occurred before the loans reach their first adjustment date, highlighting the prevalence of weak underwriting rather than the impact of rate adjustments.

\section{Changing market conditions and the prevalence of prepayment penalties have curtailed the ability of borrowers to refinance before teaser interest rates}

expire. Many borrowers took out subprime ARMs with the intention of exploiting house price increases and refinancing before the end of the teaser period. High prepayment rates have been prevalent on subprime ARMs. Foote, et al (2008) show that up to 60 percent of the subprime cohorts from 2001 to 2004 prepaid at or before 24 months of loan life. Prepayments for the 2005 and 2006 cohorts slowed dramatically, to about a 50 percent cumulative rate before 24 months for the 2005 cohort, and slower still at 20 months for the 2006 cohort. Declining house prices are inhibiting the ability of highly leveraged 2005 and 2006 borrowers to refinance. Also, an estimated 70 percent of subprime loans carry prepayment penalties as opposed to 2 percent of prime loans (Berson, 2006, Center for Responsible Lending, 2008).

Geographic concentration of subprime lending has increased loss severity. Agarwal, et al (2008) find that subprime loans tend to be concentrated geographically. In their study of the Phoenix, Arizona area, they find that subprime loans are found in primarily older neighborhoods in the inner city. As foreclosures surge in these older neighborhoods, they find that house prices decline more than in neighborhoods (or zip codes) with higher concentrations of prime loans. Thus, it is important to understand that high-risk lending in geographically concentrated areas can result in "default cascades" where they decline in property value can contribute to the decline in neighboring property values and increasing loss severities in these neighborhoods. 
As house prices have fallen and interest rates risen, subprime defaults and foreclosures have risen more than expected, but not necessarily because of ruthless defaults. As highly leveraged borrowers find themselves with mortgage debt greater than the value of their homes, it is to be expected that many would "ruthlessly" default, leave the lender with the cost of disposing the property, and accept the damage to their credit records. Foote, et al (2008) show that the issue with falling house prices stems from the resulting vulnerability to personal financial shocks rather than the tendency to ruthlessly default. Households that have positive equity can sell or refinance, but those with negative equity and a personal financial shock such as job loss are more likely to be forced into foreclosure.

Sixty percent of vintage 2006 subprime loans were made on a "stated income" basis, without any documentation or verification of the income of the borrower (Fitch, 2007). In considering the debt to income ratio, it is standard practice to verify the loan applicant's income with evidence such as pay stubs, direct verification by employer, or tax returns. In emerging markets, informal borrowers may submit rent receipts, utility bills, payoffs of appliance loans, or contracted savings accounts. Less polite industry terms for stated income loans included "no doc," "low doc," or "liar loans." While convenient for the borrower, such loans carry spreads of up to 500 basis points above prime lending rates. Stated income loans can make sense when the lender verifies assets and employment, and when the borrower has significant cash equity in the transaction. Historically, stated income loans have been made in limited numbers for self-employed professionals, or to refinance existing loans held by the lender. The lender could save time when it was familiar with the property, comfortable with the LTV of the new loan and with its knowledge of the borrower's willingness and ability to pay.

However, stated income lending became more widespread in the industry and it became riskier as lenders offered such loans on the expectation of rising house prices and without verifying assets. Studies cited by the OCC showed that borrowers exaggerated their income on 90 percent of surveyed stated income loans, that most incomes were exaggerated by more than 50 percent, and that many lenders and mortgage brokers were aware that the borrower lacked the income to pay the loan (Dugan, 2007).

Stated income loans have performed worse than other subprime loans. According to rating agency analysis, 67 percent of early payment defaults for the 2007 vintage were low or no documentation loans (Fitch, 2007). Now that attention is focused 
on rising subprime defaults, and regulators like the OCC have begun to pay more attention, many lenders have stopped offering stated income loans.

Higher LTV and debt-to-income (DTI) ratios were accepted for both prime and subprime loans. LTVs rose in two respects: 1) higher LTVs accepted at purchase, and 2 ) equity extracted by refinancing an appreciated house. Mian and Sufi (2008) found that LTVs and DTI ratios rose substantially in the early 2000s. Foote, et al (2008) found that in New England, for borrowers with FICO scores less than 620, LTV ratios on purchase and refinance loans rose from 82 percent in 1999 and 2000 to 92 percent in 2005 and 2006. DTIs for similar borrowers rose from 36 percent in 1999-2000 to 43 percent in 2005-2006. For high FICO scores, average LTVs rose to almost 95 percent, and DTIs rose from 36 percent to 42 percent.

At time of purchase, lenders accepted increasingly higher LTVs, including the possibility of financing 100 percent or more of the house price with a straight first lien, or with simultaneous first and second lien mortgages, known as "piggyback" loans. More traditionally, mortgages with LTVs greater than 80 percent have been made available only with mortgage default insurance. Piggybacks enabled borrowers to avoid paying for mortgage insurance, and until 2006 provided a tax advantage since interest on the second lien was tax deductible, but the MI premium was not. Piggybacks made up more than 35 percent of subprime originations in 2006 (Fitch, 2007). ${ }^{8}$ Calhoun (2005) documents reporting and risk issues with piggyback lending. These include regional concentrations of piggyback lending to improve affordability. Overall, higher LTV levels and debt burdens coupled with subsequently falling house prices and employment losses created a greater probability of negative equity and default.

Many foreclosed borrowers put little money dow $\mathbf{n}$ and had lived for a short time in their homes. Foote, et al (2008) report that in New England in 2007, 40 percent of foreclosures were of mortgages with zero down payments, and that 40 percent had owned their homes for less than three years. Since in Massachusetts, foreclosure usually takes 6 months or more, most recent foreclosed borrowers spent little time in their homes before financial problems occurred. In the current downturn in New England, house prices have fallen 12 percent between the first quarter of 2006 and the first quarter of 2008. During this period, unemployment has fallen 0.4 percent, so financial pressure on owners remains muted. 
Many foreclosures have been for subprime loans to formerly prime borrowers Foote, et al (2008) show that 70 percent of homes lost to foreclosure in 2006 and 2007 in Massachusetts were initially purchased with prime loans, but 45.2 percent of defaulted mortgages were subprime. The 45.2 percent is higher than 30 percent because many borrowers who purchased homes with prime loans later refinanced into subprime and then defaulted.

Private and public mortgage insurance (MI) lost market share as a method of credit risk mitigation for lower income borrowers and for borrowers that make low down payments (Chart 3). MI plays several constructive roles in the mortgage market. First, it indemnifies lenders and investors against default by high LTV borrowers. In so doing, it contributes to access to finance for buyers that lack the savings for a 20 percent down payment. By indemnifying against loss and acting as a separate source of capital in severe economic downturns, MI contributes to financial system stability. To be eligible for $\mathrm{MI}$, a lender has to adhere to the mortgage insurer's standards for credit underwriting and management, and so MI providers are important in establishing such standards. Ml providers play a part in maintaining credit standards, because they monitor the loans that they insure. During the subprime boom, loans backed by private MI fell from 17 percent of originations in 1995 to 9 percent in 2006, even as average LTVs rose. The market share for FHA and VA-insured loans fell much further, from 18 percent of originations in 1994 to 3 percent in 2006. As the boom ended, private MI market share has risen again, reaching 15 percent of originations at the end of March, 2008. The Federal government has turned to the FHA to refinance loans for troubled subprime borrowers, and its market share has risen slightly, to 8 percent at the end of March, 2008 (Inside Mortgage Finance, 2008). 


\section{Mortgage Insurance Loses Market Share in the Boom, Regains in the Bust}

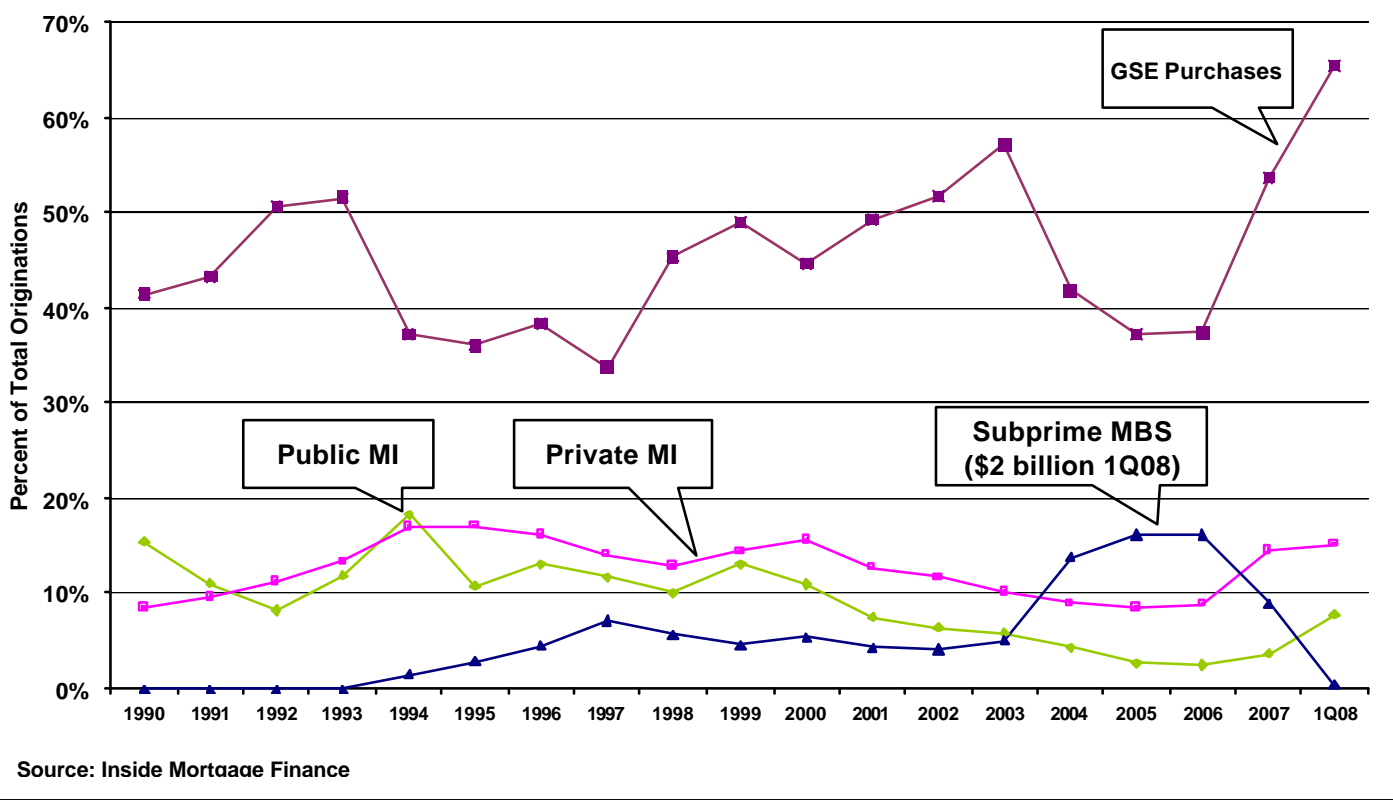

WIth sImIar incomes. At the end of December, zoU/, 14.4 percent of all subprime loans and 20.4 percent of subprime ARMs were seriously delinquent. At that time, 6.0 percent of all FHA loans and 8.72 percent of FHA ARMs were seriously delinquent (MBA, 2008). Likewise, in the states most affected by subprime defaults, the delinquency rate for FHA loans was substantially lower. ${ }^{9}$

The extension of subprime lending was supported in part by the increased use of credit scores without adjusting models and assumptions to reflect changing market conditions. Econometric models permit lenders to adjust the price of loans to reflect the expected and unexpected risk of making loans to lower and moderate income borrowers. I mproved risk-based pricing has been a boon to the financial industry overall, and reflects industry best practice for financial risk management. However, in the case of subprime lending, default models have not kept up with the evolving market, and so 
subprime default rates have surprised investors and lenders. The models particularly seemed to have missed the growing likelihood of default that resulted from the rise in interest rates that began in 2005, the slowdown in house price appreciation that started in some markets in 2005 and gained momentum in 2006 and 2007, and loosened underwriting standards (J affee 2008, President's Working Group 2008).

The layering of separate risks has compounded analytic errors and led to unexpected levels of defaults. In addition to the weakness of scoring models for the separate elements as discussed above (stated income, high LTV, house price declines), the combination of these elements has proved to be an issue in the subprime crisis. If loans that lack income documentation are risky, then the same loans made at 100 percent LTV in a market that now sees falling prices are bound to be riskier still. The rating agencies have admitted that they failed to model the impact of layering one risk on another.

\section{The Subprime Boom and Access to Finance}

\section{U.S. Housing Finance Priorities}

Before subprime lending gre w, U.S. mortgage lenders reached the majority of households, and the overall housing system delivered high quality shelter to 98 percent of households. Economic growth, a relatively elastic supply of land, and the public and private financial institutions created during the 1930s laid the foundation for a market that delivers high quality shelter to more than 98 percent of households. When the New Deal housing finance institutions were created in the $1930 \mathrm{~s},{ }^{10}$ much of the housing stock was substandard, with one-third of housing units lacking sewage attachments, and 20 percent overcrowded. By 2000, only 1.1 percent of the U.S. housing stock lacked sewage hookups, even though 9.8 percent of households lived in poverty (Census, 2006). Access to financial services is widespread; between 85 and 90 percent of households have bank accounts; the majority of unbanked households are recent immigrants (Barr 2001, Caskey, et al 2006). In recent years, about 40 percent of conventional ${ }^{11}$ mortgages were made to households earning less than the median household income, 64 percent of FHA or VA-insured loans were made to households 
earning less than the median, and overall, half of homeowners earn less than the median. ${ }^{12}$

\section{U.S. housing policy has prioritized access to owner-occupied housing by increasing the supply of finance and by providing tax subsidies. ${ }^{13} \mathrm{New}$ Deal} housing finance institutions such as FHA and Fannie Mae are predominately oriented to increasing and stabilizing financing for owner-occupied single-family homes, originally by providing long term mortgages. Home ownership is further subsidized by tax benefits. These policies, along with the post-World War II economic boom, succeeded in spurring homeownership and housing quality. Garriga, et al., (2007) estimate that about half of the increase in home ownership during the 1950s and 1960s can be explained by the introduction of the 30 year fixed rate mortgage and that the more recent increase can be attributed to the acceptance of smaller down payments. The home ownership rate rose from 43.6 percent in 1940 to 61.9 percent in 1960, and peaked at 69.1 percent in the first quarter of 2005.

\section{U.S. tax subsidies for home ow nership distort investment, but are strongly supported by the building and finance industries. Fiscal benefits for ownership} include: the tax deductibility of mortgage interest paid on first and second lien loans on primary and secondary homes (maximum total indebtedness of US\$1 million); deduction from Federal income taxes of local real estate taxes paid; and since 2006, deduction of mortgage default insurance premiums (GAO, 2005, Garriga, et al., 2007). Economists widely agree that the fiscal benefits of homeownership have steered investment away from more productive uses (GAO, 2005). Glaeser and Shapiro (2003) argue that the mortgage interest tax deduction does not increase home ownership, rather it encourages existing owners to invest in larger and more expensive homes. Housing industry participants have strongly supported the continuation of tax policies that favor ownership, including the National Association of Realtors, the National Association of Home Builders, and Fannie Mae. ${ }^{14}$

\section{U.S. tax subsidies for home ownership are regressive, particularly in} comparison to rental subsidies. Given the progressivity of the Federal income tax, mortgage deductions have no value for low income households and little value to moderate income owners. ${ }^{15}$ In 2005 the total mortgage interest tax deduction claimed amounted to US $\$ 340.5$ billion (IRS, 2007a). By contrast, the major tax subsidy that 
supports the creation of new low-cost rental units, the Low Income Housing Tax Credit (LIHTC) cost the government about US\$5.1 billion in tax expenditures in 2007 (NLIHC, 2008). While almost 50 percent of homeowner households earn less than the median income, 80 percent of renter households earn less than the median (Census, 2006).

A distortion in tax policy contributed to the growth of riskier mortgage lending during the subprime boom. Until 2006, the interest paid on a second lien mortgage loan was deductible from Federal income tax, but the premium paid for mortgage default insurance was not. This disparity provided an incentive to individuals to finance 100 percent of the purchase price of a house with the combination of an 80 percent first lien mortgage and a simultaneous 20 percent "piggyback" second lien, as discussed earlier in this paper. The popularity of piggyback house purchases resulted in higher levels of indebtedness, and given subsequently falling house prices, a greater chance for negative equity. Starting in 2006, buyers were permitted to deduct from Federal taxes the mortgage insurance premium paid in connection with home acquisition debt (IRSc 2007). Once borrowers were able to deduct the MI premium, market share for MI providers began to rebound from years of decline.

\section{The Links Between Subprime Lending and Access to Finance}

Subprime lending has provided only limited access to finance. More than half of subprime loans have been for refinancing existing mortgages rather than purchasing a house (Chart 4). In the U.S., individuals frequently replace existing fixed rate mortgages with new ones to take advantage of declines in market rates or to extract equity from the house by refinancing at a higher LTV. Many subprime borrowers refinanced to pay off riskier ARM loans before they reached the end of their low teaser interest rate period. As such, refinancing represents no new access to finance. In addition, not all subprime lending has been for low-income households; many subprime loans were made to higher income earners that had blemished credit records. 


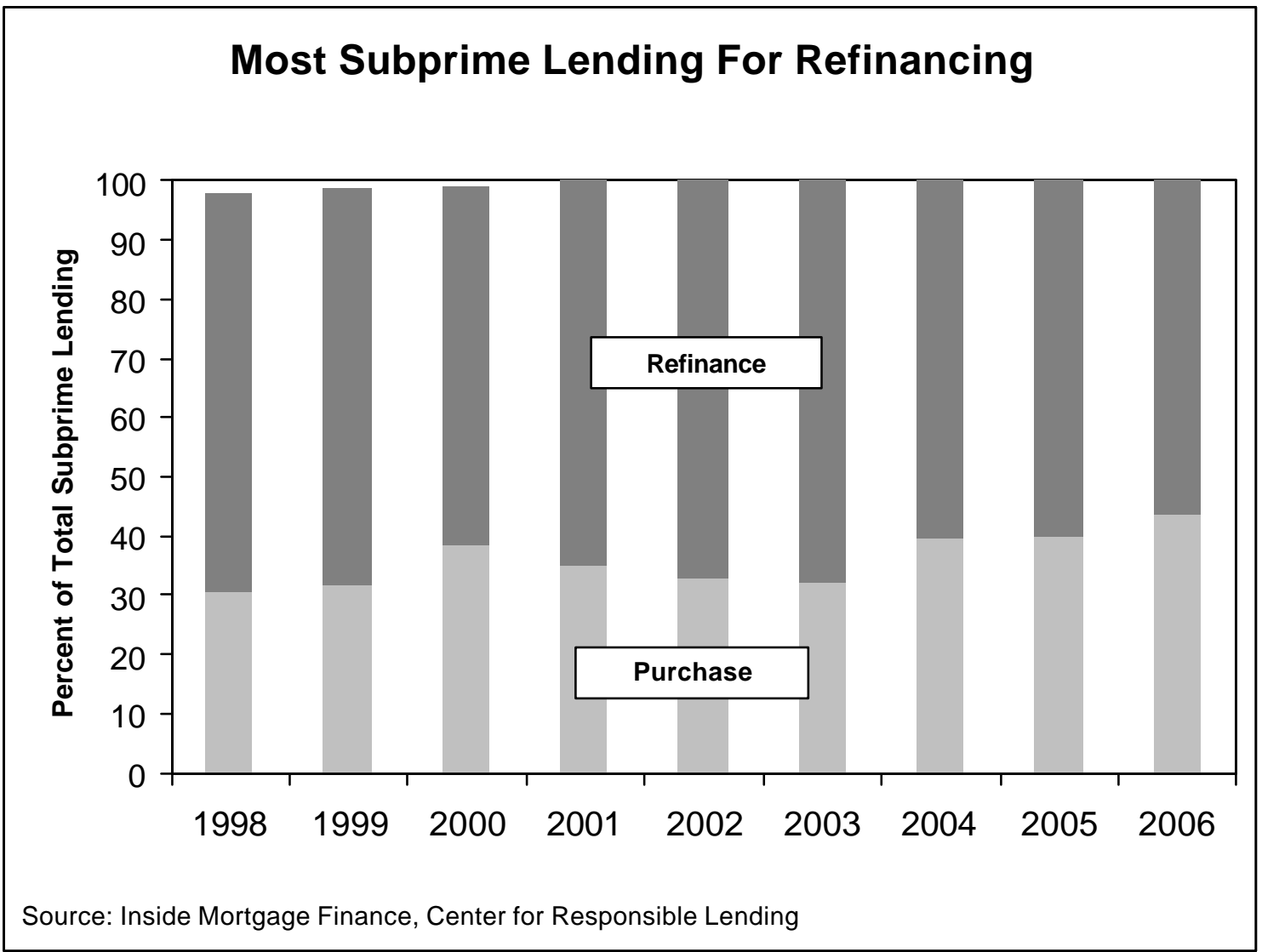

Subprime mortgage lending was made possible by liberalization of the financial system, new credit risk management technology, and policy efforts to reduce racial and economic discrimination in lending. In 1980, Congress passed the Depository Institutions Deregulation and Monetary Control Act (DIDMCA), the first of a series of laws that liberalized the financial system.. DIDMCA did many things, among them ending usury restrictions on mortgage interest rate (Gramlich, 2007). The second ingredient, credit scoring technology, came into being in the 1990s, as banks became aware of the power of historical statistics in predicting credit performance. The third ingredient was an effort to increase the supply of credit to underserved communities, 
the Community Reinvestment Act (CRA) of 1977. ${ }^{16}$ CRA requires banks to provide credit, including mortgages, to all communities in the geographical areas that they serve, including those that are predominately minority and low income.

In the 1990s, lenders came to realize that lending in low-income neighborhoods was profitable, so long as they could charge an interest rate that was sufficient to compensate for the risk of lower credit scores. As CRA required banks to lend more in low income neighborhoods, banks did so using credit scoring to evaluate ability and willingness to pay, and to charge higher rates of interest to clients that credit scores showed to be riskier. Prior to the 1990s, mortgage lending had been characterized by uniform pricing among individuals for a given loan type. During the 1990s, credit scoring gave lenders an objective means to price discriminate on the basis of credit risk. Consumer lending, and particularly mortgage len ding, evolved to where many individuals that previously were denied credit were now granted credit, but at prices that varied with their credit scores (Avery, et al., 2007, Chomsisengphet and Pennington-Cross, 2006, Gramlich, 2007).

The role of subprime lending in raising the ownership rate is not clear and its sustainability is questionable. Data limitations make it difficult to determine how many first time homebuyers gained access to mortgage credit for the first time thanks to subprime lending. Jaffee (2008) estimates that subprime lending may have enabled 1.38 million first time home purchases nationwide between 2000 and 2007. This would be about 20 percent of the increase of 6.59 million owners over the same period or 1.8 percent of the 75.1 million overall owner-occupied units in the country in $2006 .{ }^{17}$ To the degree that first time buyers subprime had high LTVs and now are in negative equity positions, or have loans with high debt-to-income ratios, and teaser rates that have adjusted radically higher, the addition to ownership is likely to prove short lived. The Center for Responsible Lending has estimated that over 2 million subprime loans will eventually end up in foreclosure. If this turns out to be the case, then the net effect of subprime lending on homeownership would be negative.

The U.S. home ownership rate rose moderately between the 1980s and 2006, including the years of the subprime boom, then fell somewhat. By the first quarter of 2008, the overall ownership rate had dropped to 67.8 percent from its 2005 
peak of 69.1 percent, a drop of 1.44 million units, given the occupied stock of 110.8 million occupied units at the end of April, 2008 (Census, 2008).

The current U.S. home ownership rate is among the higher of Western European countries with equally sophisticated mortgage finance systems. Ownership rates in Western Europe range between 45 and 82 percent (Table 1). Ownership in many emerging markets ranges between 70 and 85 percent, reflecting in some cases weaker forms of tenure and lower quality units (South America), and in others massive and sometimes costless privatization of the formerly public housing stock (Eastern Europe).

\begin{tabular}{|c|c|}
\hline \multicolumn{2}{|c|}{ Table 1 Selected Home Ownership Rates } \\
\hline Country & $\begin{array}{l}\text { Home Ownership in } \\
\%\end{array}$ \\
\hline Germany & $45 \%$ \\
\hline Denmark & $49 \%$ \\
\hline United Kingdom & $69 \%$ \\
\hline Spain & $82 \%$ \\
\hline Latvia & $77 \%$ \\
\hline Slovak Republic & $85 \%$ \\
\hline Slovenia & $84 \%$ \\
\hline Colombia & $55 \%$ \\
\hline Nicaragua & $75 \%$ \\
\hline \multicolumn{2}{|c|}{$\begin{array}{l}\text { Figures for Europe are for 2004, for Latin } \\
\text { America for } 2000\end{array}$} \\
\hline $\begin{array}{l}\text { Source: Federcas } \\
\text { Spilerman }(2007)\end{array}$ & 6), Torche and \\
\hline
\end{tabular}

The U.S. national homeownership rate may never rise much higher than 75 percent. Regional disparities in ownership rates reflect differing housing costs, with ownership levels somewhat higher in the Midwest ( 72 percent) and South (69.7 percent) than the Northeast ( 64.7 percent). Disparities between age groups reflect life cycle factors, with ownership rates higher for older households that would be expected 
to have saved more and to be more settled. Ownership levels within age groups have been relatively steady for some time. For example, the rate for owners under 35 was 39 percent in 1985, rose to 43 percent in 2003, and dropped to 41.3 percent in the first quarter of 2008. It may be that access to lower down payment loans has made ownership available to as many younger households as can afford to buy or that want to (Census, 2008, 1999, Garriga, et al., 2007). The greatest remaining disparity is with respect to race, which reflects differences in income among racial groups and, to a lesser extent than in the past, discrimination. ${ }^{18}$ The ownership rate for Blacks rose from 46.3 percent in 2000 to 48.1 percent in 2005 , and then fell to 47.1 percent in the first quarter of 2008. The Hispanic ownership rate rose from 45.7 percent in 2000, to 49.4 percent in 2005, and then fell to 48.9 percent in 2008. Median household income for Blacks was 61 percent that of whites in 2006, and that of Hispanics was 72 percent that of Whites (Census, 2008). Income disparities between racial groups narrowed between the 1960s and 1990s, and ownership rates among minority groups rose during that period. If incomes and ownership rates among Blacks and Hispanics were to rise to the level of White-headed households, the overall ownership rate would rise to 75 percent.

\section{Weaknesses in Secondary Market Practices}

Between 2001 and 2006, between 60 and 80 percent of subprime loans were bundled into mortgage-backed securities and sold to investors in capital markets (Inside Mortgage Finance, 2008). This is in contrast with the bank lending model followed in most emerging markets, where banks originate and hold the loans in their portfolios, fund them with deposits and retain the risk of default. Securitization in the U.S. has clear benefits because it taps the bond market, which is less expensive on a riskadjusted basis than funding with deposits. Securitization permits banks more flexibility in managing capital allocation as they are able to monetize long maturity assets and sell credit risk to the capital market.

\section{I ncreased Moral Hazard Problems}

Securitization comes at a cost, which is that there is a risk of moral hazard. Lenders that originate then sell the loans to another party (investors) have incentives to originate and sell loans that are riskier than they would originate if they had to hold 
them in their portfolios. For securitization to work properly there must be a means to control moral hazard. This could be through a third party agent, such as a credit rating agency (CRA) or through a contractual arrangement, such as requiring lenders that sell portfolios to retain capital against the performance of the portfolio, or to retain a subordinated portion of the security that is eventually issued. When the moral hazard problem is not controlled and defaults rise above what has been expected, investors are exposed to additional unexpected risks.

What are the moral hazard problems with the securitization market? The basic structure of the U.S. residential mortgage securitization market is found in Figure 1. Essentially, a lender makes the loan to a borrower based on an evaluation of the borrower's credit risk. The lender then sells the loan to a third party (aggregator) that bundles it with other mortgages and issue bonds based on the cash flow of the entire assembled loan portfolio. Federal government sponsored enterprises (Fannie Mae, Freddie Mac) buy most conforming loans (loan amount of $\$ 350,000$ and excellent borrower credit).

Investment banks buy loans over the conforming limit (jumbo loans) and they buy credit impaired or subprime mortgages. The jumbo and subprime markets together are termed the "private label" or nonagency market. ${ }^{19}$ The investment bank bundles the loans into a pool and then underwrites the pool and sells bonds (or tranches) based on the pool to investors. At each point in the process, the investor is relying on the underwriters to have properly underwritten the loans and the pool of loans. Given that the lender has the option to retain loans for the bank's portfolio, one must consider whether the lender has sold the lower quality loans to investors through the securitization markets. In other words, did the lender sell its "lemons" to investors. ${ }^{20}$ 
Figure 1

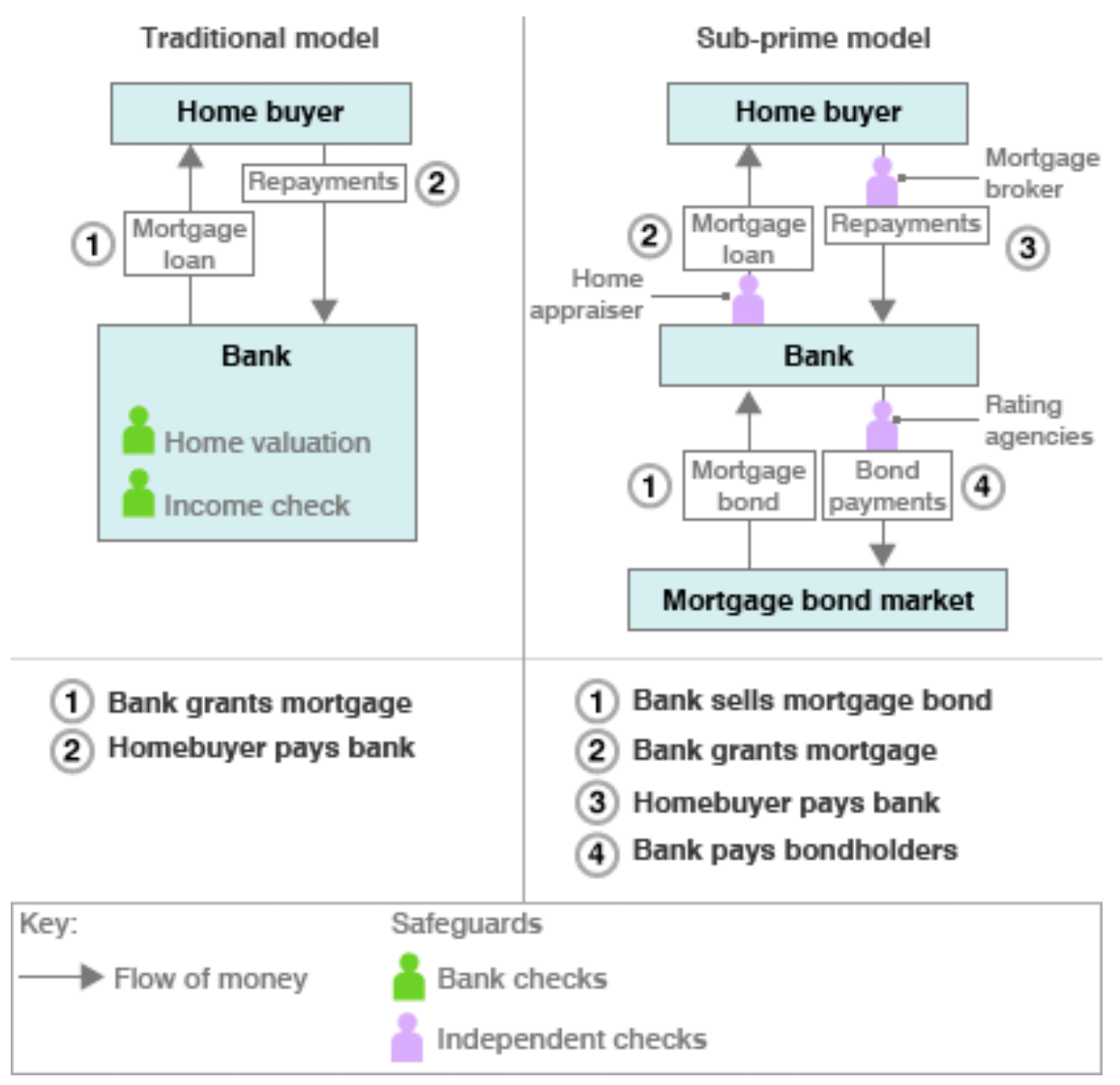

Market disclosures and contractual constraints failed to prevent weak practices in subprime underw riting. Contractual representations and warranties in securitization documents require that the loan originator repurchase or make whole the investor for mortgage loans that were not made according to what was promised by the lender. That is, if investors (or another party) discover that the loans were inappropriate or that underwriting was not sufficient, the investors can require that the lender repurchase the tainted loans. Typically, the offering memorandum for a subprime assetbacked security deal will convey these representations and warranties that supposedly protect investors from poor origination and underwriting by the lender. The mortgage loan purchase agreement (MLPA) details the representations and warranties covering 
the lender's origination and underwriting. While this seems sufficient to overcome the potential moral hazard problems associated with the lender, there are two problems associated with relying on representations and warranties to solve the moral hazard problem. First, the lender can challenge the claims in court and such cases may last several years. Second, lenders like New Century Financial did not maintain sufficient capital to cover all claims. Since lenders can file for bankruptcy protection, the lender will in practice tolerate only a certain level of repurchase claims. In practice, many lightly capitalized subprime mortgage lenders were bankrupted in 2006 and 2007 because they lacked the funds to make good on investor claims to repurchase early defaulting loans out of the pools. Thus, the representations and warranties requiring lenders to repurchase tainted loans may not be an effective tool in a default wave such as has been occurring in the U.S. during 2007 and 2008.

\section{Not Fully Understanding B/ C Lending}

The desire for issuance volume and yield led lenders, securitization conduits, and investors dow n market. When interest rates increased dramatically in 1994, mortgage originators sought ways to offset the dramatic drop in refinancing applications. In their search to preserve market share and fully utilize existing servicing capability when loan originations slow down, lenders sought to identify borrowers who were previously undetected, underserved, or underqualified. Conforming loan MBS (such as Fannie Mae and Freddie Mac MBS) tend to refinance rapidly when interest rates drop. Therefore, to insulate investors against faster prepayments, investment banks sought to purchase loan types that were known to prepay more slowly, such as subprime. Many originators broadened their market base by developing or expanding not only the subprime (also known as $\mathrm{B} / \mathrm{C}$ ) credit programs but "alternative" A-credit borrowers that did not fit either the agency-conforming or standard jumbo underwriting criteria.

\section{Assumptions about the performance of subprime borrowers and securities proved to be inaccurate. B/C borrowers generally accept mortgage loans with high interest rates because they cannot qualify for anything else at the time of loan origination, and their loan amounts are typically lower than for A-quality loans. Thus, these borrowers are expected to be less sensitive to interest rates because of the restricted opportunities to refinance and the limited dollar reduction in their debt service. In addition, subprime loans typically have prepayment penalties while conforming loans}


do not. On the other hand, overall B/C prepayment speeds are inherently fast because these borrowers are motivated to refinance into an A-quality loan as soon as their credit position improves. Under these prepayment assumptions, securities backed by B/C loans should be shorter and yet less callable - precisely the characteristics sought by many ABS investors. However, these assumptions were untested by experience, and could unravel, as conforming MBS assumptions did, if subsequent product innovation provided appealing alternative financing for credit-impaired borrowers. ${ }^{21}$

In the jumbo loan sector, borrowers that fail to satisfy one or more of the standard credit underwriting guidelines were seen as a good underserved market to address, in conjunction with property-based lending. In the 1990s, these borrowers were attracted to the limited documentation ("limited doc") or no documentation ("no doc") programs in which the lenders waived most of the documentation required to demonstrate the borrower's financial strength (in other words, "don't ask, don't tell") in return for a large down payment. "No doc" programs were also known as "equity lending" because the loan quality depended entirely on the value of the underlying real estate. Lenders believed that increased borrower equity would reduce the probability of default and mitigate losses in the actual event of default.22

Unfortunately, lenders miscalculated. "Limited doc" loans rapidly became the worstperforming sector of the nonagency MBS market. ${ }^{23}$ The most spectacular failures were due to borrower fraud, particularly fraudulent appraisals (which misrepresented the LTV ratio) and "silent second" mortgages (i.e., second mortgages taken out simultaneously with the first mortgage, unbeknownst to the first lien mortgage lender, thus misrepresenting borrowers' debt ratios and equity contribution). However, even mainstream lenders experienced much higher-than-anticipated losses on their limited doc portfolios, for several reasons:

- Adverse selection: The near- total lack of borrower disclosure attracted genuinely weak borrowers, rather than creditworthy ones who failed to qualify on a technicality. ${ }^{24}$

- Payment-induced borrower default: Most limited doc loans were ARMs because they were more likely to have to remain in the lender's portfolio; and the combination of 
deep teaser rates and rising interest rates caused payments to increase dramatically through the late 1980s. ${ }^{25}$

- Vanishing equity: When the real estate market turned sour, prices on distressed properties dropped much faster than the overall average, which rapidly deflated the equity cushion. ${ }^{26}$

- Search for additional volume: Originators and investors, seeking to retain and grow profitable fee- based business volume moved progressively down market to ever lessqualified borrowers.

\section{Not Understanding New Mortgage Designs}

Investors in the subprime and jumbo markets lacked data to evaluate the performance of new mortgage instruments such as option ARMs, 2/28 ARMs, and others. ${ }^{27}$ These newer loan instruments cannot be evaluated with data for other loan designs in rising property markets. It has been suggested that loans with adjustable rates are a big part of the problem, but such loans are not new. Adjustable rate mortgages have been a part of the U.S. market for some time, but more to the point, they have been the main type of mortgage in countries like Canada and the U.K. for some time without major disruption. What was unknown (due to a heavy reliance on historical data) was how a slowdown or turndown in the housing market would affect defaults of ARMs with new and complex features as they were extended to a broader population of households, many with more limited resources.

Data from Loanperformance.com shows that there has been a sharp increase in late payments among recently originated (2006) subprime loans, but these increases have been well before rate changes would take place Demyanyk and Van Hemert (2007). So at least some of blame is due to other characteristics of the loans and/or borrowers. It will take months or years before it is known which characteristics have been the most important. 


\section{Not Fully Recognizing the Adverse Selection Problem}

There is evidence that a number of borrowers gave misleading information about their income and operated under the assumption that they could refinance their way out of problems. When housing prices started declining, they discovered that this was more difficult than expected. That so many loans have been delinquent almost immediately after origination suggests that not all borrowers have been victims. In some cases, the borrowers went along with deceptive schemes to fool the underwriter (and loan purchaser).

There is evidence that a number of borrowers took out loans knowing in advance that they could not afford the mortgage payments when an ARM reset took place. These borrowers were effectively speculating on housing prices, hoping for an increase in housing values so that they could sell their properties for a gain before the reset occurred.

More broadly, there were plenty of incentives for borrowers, lenders, and investors to have protected themselves. While it may be the case that investors in the AAA tranches of subprime structures had little incentive to look closely at risks, the investors in the subordinated tranches certainly had such an incentive. It looks like they will bear the brunt of losses, and it is unclear so far why they, who were supposed to be the specialists in risk management, were so wrong.

\section{Not Fully Understanding the Shortcomings of Credit Rating Agencies}

Credit Rating Agency models were misapplied. The credit rating agencies (CRAs) (Moody's, S\&P, Fitch) provide ratings for credit-sensitive products such as subprime Asset-backed Securities (ABS). Investors around the world rely on the ratings agencies' assessment of risk for the underlying collateral and the structure of the ABS tranches. Unfortunately, the ratings agencies were delayed in downgrading the ratings on $A B S$ tranches, waiting until after the problems had already begun. ${ }^{28} \mathrm{~A}$ partial explanation for the ratings agencies being slow to react to the deteriorating credit conditions in the subprime market is that their risk models are historically based. Subprime defaults during 2004- 2006 were low and house prices were increasing (given little incentive for subprime borrowers to default). However, the slowdown and decline of house prices led 
to a sudden increase in delinquencies and defaults in the subprime sector. So, it is not surprising that historically-based ratings would take a while to adjust to the downturn.

In addition to being slow to downgrade subprime ABS, the ratings agencies may also suffer from the incentive structure inherent in their business model. Issuing investment banks pay the rating agencies to analyze and rate the collateral underlying credit sensitive MBS and ABS. Two ratings are typically used. Given that there are more than two rating agencies, a potential problem surfaces when the issuing investment banks pay for the ratings, in that a ratings agency could give favorable ratings in return for repeat business. However, the incentive for ratings agencies to be overly generous with their ratings must be offset by the reputational effects of being too generous; that is, the ratings agencies must maintain credibility to generate repeat business.

\section{Rising Loss Severity I ncreases the Incentive to Modify Loans}

Loss severity on subprime loans has reached 45 percent. According to a study by Standard and Poor's, loss severity on a subprime mortgage has reached $45 \% .{ }^{29}$ A loss severity of this magnitude makes it a prudent decision to recast the subprime mortgage if the savings from avoiding default outweighs the cost of reducing the interest rate on the loan. Unfortunately, there are a large number of investors in the subprime market, so loan modifications as a means to avoid foreclosure can vary dramatically across borrowers,

Loan modifications as a course of action. In order to minimize losses, the servicer on a loan (the party to whom the mortgage payment is sent and the party that monitors the performance of the loan) can recast or change the terms of the mortgage loan. For example, the servicer can ext end the loan (e.g., 300 months remaining extended out to 360 months remaining in order to lower mortgage payments), lower the mortgage interest rate, or convert the loan to a different, lower risk product (e.g., adjustable-rate to fixed-rate mortgage). The problem becomes more complex if the loan has been sold to an investor since the servicer is charged with operating in the best interest of the investor. So, the question is as follows: would the investor (or financial institution) be better off keeping the loan terms as is and suffering the default and subsequent loss severity or modifying the loan terms in order to avoid a default. 
Short sales as an alternative to loan modifications. If loan modification is not possible, another approach potentially available to the borrower is the "short sale," Since a typical foreclosure can result in a loss severity of $45 \%$, a lender may be willing to settle for an amiable settlement by having the borrower sell the house and give the proceeds to the servicer. While the investor (lender) still suffers the loss of the house price, it avoids the other costs of foreclosure such as interest expense, property taxes, legal fees, and maintenance that would result from a prolonged foreclosure. Often, the borrower asks the servicer/lender not to enter the short sale as a default since this would destroy the borrower's credit score. Lenders generally only agree with such a course of action if the borrower is destined to default. There are a variety of circumstances where the borrower is destined to default such as job loss, job transfer and medical issues.

\section{Regulation of Subprime Lending and Securitization}

\section{The I mportance of Systemic Effects}

Most market observers and participants failed to anticipate the threat to system stability that subprime lending posed. In the words of the IMF (2008), there was a collective failure to appreciate the extent of leverage taken on by a wide range of institutions. Subprime lending has been a relatively small part of overall U.S. mortgage lending, rising to 20 percent of mortgage lending for its peak years of 2005 and 2006, but averaging 7 percent between 1994 and 2007, and ending up at about 12 percent of outstanding mortgages by 2006 (Inside Mortgage Finance, 2008). The subprime mortgages with the highest default rate were predominately made by nondepository lenders and sold to sophisticated institutional investors that were expected to understand and manage risk. Aside from the failure of investors to exercise due diligence, there was only a limited understanding on any observer's part of the cumulative extent of leverage within financing structures, at hedge funds, and in offshore investment vehicles created by banks outside the U.S.

Before systemic effects began to be felt in 2006, the regulatory debate in the U.S. was limited to protecting unwary borrowers and traditionally underserved groups from lenders that charge exorbitant fees or that provide unsuitably risky loan products (GAO 
2004, OCC 2006, Gramlich 2007). Until the crisis, there had been no consideration of the compounded effect of leverage and term mismatch taken on by foreign investment funds, such as the SIV set up in Ireland by the German Landesbank Sachsen LB, that financed medium and long term CDOs with short term commercial paper. There has not been a broad understanding of the exposure of banks to hedge funds such as the Carlyle Capital Corporation, the mortgage fund that failed in March, 2008. ${ }^{30}$ These funds depended on bank debt to leverage their investments and increase their return on capital.

\section{Non-Depository Mortgage Lenders Weakened Their Underw riting Standards}

Lightly regulated non-bank financial companies linked weak subprime credit underw riting with international capital markets. The majority of the riskier adjustable rate subprime loans were originated by non-bank mortgage bankers and brokers that originated the loans for securitization, frequently referred to as the "originate to distribute" model. Mian and Sufi (2008) show that the growth in supply of mortgages by non-bank lenders under the originate to distribute model was associated with a decline in underwriting standards and an eventual rise in defaults. The resulting securities were sold to institutional investors, primarily private hedge funds and other asset managers for the riskiest structured credit products. Monoline credit insurers provided credit enhancements to subprime securitization transactions, and have suffered significant erosion in capital as defaults rose. Mortgage bankers and brokers are not subject to prudential supervision. As private investment firms, hedge funds have no disclosure requirements, and insurers generally face different capital standards than do banks.

Where non-bank mortgage lenders have been created, including in the U.S. Mexico, and Asia, it has been thought unnecessary to supervise them. Since mortgage brokers and bankers are funded in the capital markets, it has been expected that their debt and equity investors should be expected to understand and manage risk. When they are a small part of the financial system, mortgage brokers and financial companies do not pose a threat to stability. With this approach in mind, the Mexican government in 2005 clarified the regulation of non-bank lenders, creating a new and more flexible entity in law that permits a wider range of activities. ${ }^{31}$ Similarly, prior to the 1998 Asian crisis, non-bank financial institutions (NBFIs) lacked supervision, and their lending for real 
estate, margin loans for equity, consumer finance and car purchases were an important source of risk. The erosion of the distinction between banks and NBFIs led to compromise in credit underwriting criteria, with the finance company affiliates of banks extending credit that the banks were precluded from extending, due to prudential norms, such as legal lending limits (Pomerleano, 2002).

In the U.S., non-bank mortgage lenders take two forms: mortgage banks and mortgage brokers. Non-bank mortgage lenders are uncommon in emerging markets, generally because they lack the means to either sell loans or to fund long term mortgages on their balance sheets. ${ }^{32}$ Mortgage banks accumulate portfolios of loans and sell them to depository lenders or to securitization companies. Mortgage banks finance the accumulation of portfolios with short term lines of credit from commercial banks. Historically, the business model for a mortgage bank was to originate loans for sale to Fannie Mae and eventually, Freddie Mac and Ginnie Mae. ${ }^{33}$ But these enterprises only buy loans that adhere to their credit quality standards. The mortgage banker retained the right to service the loan, and made most of its profits from the stream of servicing fees, as much as 25 basis points per loan per year. In the 1980s and 1990s, economies of scale in servicing led to increased specialization, and smaller mortgage bankers increasingly sold their servicing rights to larger servicers that could more efficiently exploit investments in computer systems and customer call centers.

Mortgage brokers have a different business model. They act as sales agents for lenders. Brokers never own the loans that they originate; they simply identify borrowers and process the application on behalf of the lender that they represent. Once the actual lender approves a loan for a mortgage broker client, the broker collects a fee and has no further stake in the loan's performance.

Since investors did not insist on underwriting standards, the originate-to-sell model led to riskier subprime lending. Enforcing strict underwriting standards is labor intensive and expensive, especially for mortgage brokers that operate on thin profit margins. Adhering to strict underwriting reduces the volume of loans. A lender that enforces strict standards necessarily denies credit to some applicants.

In theory, non-bank lenders have four incentives to maintain high underwriting standards: 
- Lenders that originate to sell need to maintain a reputation for originating high quality loans or they are not able to sell them During the subprime boom, this incentive was weakened as investors accepted increasingly risky collateral, such as no-documentation loans. At the same time, the practice of paying yield spread premiums to brokers provided them with an incentive to maximize the interest rate charged on the loan.

- Investment banks and security investors traditionally monitored samples of loan portfolios and rejected loans that failed to meet standards. However, such "due diligence" broke down as investors demonstrated a willingness to buy any collateral so long as the yield was sufficiently high. Investment banks either performed due diligence reviews themselves or hired firms to undertake the reviews for them. One of these firms, Clayton Holdings, has agreed to cooperate with New York state prosecutors in lawsuits against the investment banks that hired them. According to press reports, Clayton Holdings has told prosecutors that starting in 2005, it saw a significant deterioration of lending standards and a parallel jump in lending exceptions that were permitted, and that some investment banks directed it to reduce the number of loans it evaluated in each portfolio (NYT, 2008). Engel and McCoy (2007), provides the following language from a prospectus for a Merrill Lynch subprime issue:

With the exception of approximately 20.82 percent of the mortgage loans in the statistical mortgage pool that were underwritten in accordance with the underwriting criteria of The Winter Group, underwriting criteria are generally not available with respect to the mortgage loans. In many instances the mortgage loans in the statistical mortgage pool were acquired by Terwin Advisors LLC from sources, including mortgage brokers and other nonoriginators, that could not provide detailed information regarding the underwriting guidelines of the originators.

For 80 percent of the loans in this pool, no information was available that would allow the investor or the credit rating agency to quantitatively judge the default probability or expected loss given default. Nevertheless, the pool went to market as collateral for a rated security. 
- Mortgage bankers are required to repurchase loans that default too quickly, for instance before the first or second payment is due, or that are defective or fraudulent in their documentation. Mortgage bankers are required to maintain accounting reserves against repurchases. However, the small reserves that they maintained in practice proved entirely insufficient against the wave of repurchase demands that surfaced as early payment defaults rose in 2006 and 2007. 34 These demands forced many mortgage banks into bankruptcy.

- Traditional MI provided a third party quality control of the credit underwriting process. Lenders and investment banks bypassed this role by using simultaneous second liens at origination, by structuring the securitization with deeper subordination, and by purchasing credit enhancements from monoline insurers. But these substitutes included no third party review of the loan documents

Non-bank lenders dependent solely upon securitization found themselves unable to sell their loans once the crisis hit. The lack of funding diversity is most pressing for non-depository lenders that depend solely on securitization or portfolio sales. As the subprime crisis grew in 2007, issuance and trading in subprime and prime mortgage-backed securities stopped for months at a time as investors fled the sector in its entirety. Major lenders, such as Northern Rock in Great Britain and Countrywide Financial in the U.S., suffered serious liquidity shortages even though neither was primarily a subprime lender. ${ }^{35}$ Although each had thousands of high quality loans in its pipeline ready for sale, they could not find buyers. Eventually, Northern Rock was acquired by the Bank of England. Since Countrywide had as a part of its assets a Federally-chartered thrift, it was able to tap lines of credit at the Federal Home Loan Bank of Atlanta. Even this proved inadequate, and eventually Countrywide also was required to sell itself to a larger commercial bank with greater resources, Bank of America.

\section{Consumer Protection Failures in Subprime Lending}

Many subprime borrowers had good enough credit scores to be considered prime, but took out loans with features that made them subprime. Foote, et al (2008) report that in New England, the fraction of subprime borrowers with a FICO score greater than 620, a widely accepted cutoff for subprime, rose from 40 percent in 1999 
to 70 percent in 2004, and that the portion of high- FICO score subprime borrowers rose in nationwide datasets over the same period. However, at the same time, other risk measures, such as rising LTVs and DTIs deteriorated for these same borrowers. Some high- FICO score borrowers may have been inappropriately steered to subprime products, but others would have had to take out subprime loans if they were to take advantage of riskier loan features.

Predatory subprime lenders have misled borrowers and convinced them to take out loans that they did not understand or that carried inappropriate risks.

Statistics show subprime borrowers to be higher risk than prime borrowers, to pay more for loans, to be predominately minority, to have lower income, be less well financially educated, and less likely to search for the best interest rates and terms for their mortgage loans. ${ }^{36}$ In an attempt to comply with underwriting rules, some brokers persuaded borrowers to mis-state income or assets, or convinced borrowers to sign blank application documents that the broker would later fill in with false figures that would be sufficient to have the loan approved. In one FTC case, a subprime lender presented the loan in Spanish for Spanish-speaking borrowers, but provided documentation in English that the borrower was unable to read, and that was materially different from the oral promises made about the loans. A commonly cited practice has been "fee packing", where excessive processing fees are included in the balance of the new loan, increasing the borrower's indebtedness without providing value. About 70 percent of subprime loans carry prepayment fees, compared to about 2 percent of prime loans. Other practices include charging rates of interest much higher than those charged for other borrowers with similar credit histories, misleading borrowers about the costs of the loan by failing to disclose the costs of required taxes and insurance, and abuses in servicing, such as refusing to correctly credit payments received and then declaring borrowers to be in default. (Tomkin, et al., 2002, Lax, et al., 2004, GAO, 2004a, FTC 2007, Renuart, 2004.)

Penalties for predatory lending are small in comparison to the potential gains for lenders. The penalty which lenders face when found guilty of breaking fair lending laws is to return excessive fees or charges to the affected consumers. There are no punitive damages in law for predatory lending practic es. The FTC has played the predominant Federal role in enforcing fair mortgage lending laws, ${ }^{37}$ bringing 21 actions between 1998 and 2006 against subprime lenders, resulting in $\$ 320$ million returned to 
consumers (FTC, 2007). While an significant amount, it pales in comparison to the $\$ 516.3$ billion of subprime loans outstanding at the end of 2006, and the $\$ 117.8$ billion in subprime-related losses experienced the same year (IMF 2008). Bringing fair lending cases is expensive for the agencies involved. FTC and Department of J ustice (DOJ) staffs have stated that the cost and years of litigation involved require them to carefully select the cases most likely to result in the most impact (GAO, 2004). It is likely that at least some cases that warranted prosecution have not been pursued.

\section{Industry lobbying and regulatory turf issues helped to prevent tightening of consumer protection laws for subprime lending until the crisis became evident.} In the early 2000s, calls to tighten federal regulations or to pass new national legislation were met with indifference on some parts and by strong counter lobbying by the lending industry (WSJ , 2007a). Authorities at the Federal Reserve Board ignored warnings by one of its governors and by consumer groups. Attempts to encourage the industry in 2001 and 2002 to have subprime lenders adopt a voluntary code of best practices were fruitless (WSJ, 2007b). According to data from public disclosure records, the mortgage industry contributed more than $\$ 271$ million on federal lobbying and $\$ 24.6$ million in PAC donations between 1999 and 2007 (Common Cause, 2007). Industry-sponsored legislation was introduced in 2000 and reintroduced in 2003 and 2005 to weaken consumer protection requirements. ${ }^{38}$ The industry-sponsored bill languished when one of its Congressional supporters was jailed on corruption charges. Legislation supported by consumer advocates was introduced in 2005. It would have tightened subprime reporting rules, but it failed to gain support in the Congress. ${ }^{39}$

\section{State government attempts to restrict subprime lending in their states} instigated a strong negative reaction from national government and from the mortgage lending industry. Given persistent concerns about subprime lending practices and the limited impact of Federal law, by January, 2007, a total of 27 states had passed new laws, according to the lending industry (Butera and Andrews 2006). The industry lobbied state legislatures to weaken the laws they passed, arguing that it would be uneconomic to work in an environment of inconsistent state rules. The OCC, in a decision upheld by Federal courts, exempted all national banks and their subsidiaries from adherence to state predatory lending laws. ${ }^{40}$ 


\section{The Fragmented U.S. Regulatory System Contributed to the Slow Regulatory Response}

The U.S. financial regulatory system permits mortgage lenders to move risk to where capital charges are lowest and regulatory scrutiny is lightest. The system has evolved over the years into a complex and fragmented collection of national and state agencies with competing and overlapping mandates. ${ }^{41}$ Regulatory responsibility of the separate agencies reflects institution type, since distinct financial institutions used to be responsible for distinct financial products. There is one supervisor for banks that once were specialized mortgage lenders, and another for traditional commercial banks. However, such institutional distinctions disappeared in the 1980s and 1990s with liberalization of the financial system. The result is that a given economic activity such as mortgage lending may be the subject of disparate regulatory treatment as a result of the choice that an entrepreneur makes when registering as a national bank, state bank, or as a non- bank lender. Other regulatory activities are split across agencies. The agency that has primary responsibility for writing consumer protection rules for mortgage lending (the Federal Reserve Board) is not the same as the agency that primarily enforces them (the Federal Trade Commission).

One paradoxical result of the structure of the U.S. regulatory system is that while the largest and safest lenders are subject to sophisticated and intrusive risk-based supervision, riskier non-bank mortgage lenders are subject to no prudential oversight. For instance, the San Francisco-based bank Wells Fargo \& Co. alone has 34 examiners from the OCC and the equivalent of 12 Federal Reserve examiners assigned to it. By comparison, state regulators of mortgage brokers have limited scope and resources. California's Department of Corporations has 25 examiners to oversee more than 4,800 state licensed mortgage lenders, including many of the U.S.'s largest subprime companies. ${ }^{42}$

\section{The Role of Auditors}

External auditors abetted the boom mentality by under-reporting risks and losses. In the case of New Century Financial Corporation, New Century's auditor, KPMG apparently enabled significant improper and imprudent practices related to loan originations, operations, accounting, and financial reporting processes. Among other 
actions, KPMG apparently suggested reducing reserves against possible loan repurchases in 2006 at the same time that early payment defaults rose, and New Century was "flooded" with repurchase claims from investors. The examiner indentified accounting issues with the allowance for loan losses on loans held for investment, mortgage servicing rights, deferral and amortization of loan origination fees, hedge accounting, and goodwill from an acquisition. In the third quarter of 2006, as a result of these accounting failures, New Century was said to have understated its repurchase reserve by 1000 percent, reported a profit of $\$ 63.5$ billion, and met analysts earnings expectations, when it should have reported a loss and at least a 40 percent decline in earnings per share (New Century Examiner Report, 2008).

\section{The Role of Credit Rating Agencies}

The widespread downgrading of subprime securities in 2007 severely undermined market confidence in the ratings process and in market prices for those securities. The role and supervision of Credit Rating Agencies (CRAs) has been an issue for some years in a number of financial markets (Partnoy, 2006). As noted by the IOSCO (2008), the growing volume of subprime securitizations gave the rating agencies little incentive to discourage investors from effectively outsourcing their evaluation. Regulatory requirements for investors, issuers, and banks, including in particular the Basel II capital accords, require authorities to accept the role of rating agencies on a much larger scale than has been the case in the past. However, in several important instances, ratings have lagged market developments, and have appeared out of touch with defaults, as in the case of Enron. In the wake of the financial scandals of 2000-2002, among a number of other financial market reforms, Congress requested that the Securities and Exchange Commission (SEC) review the role of CRAs and their oversight. ${ }^{43}$ By 2007, the SEC had finalized new regulations that established clearer standards for the recognition of CRAs. IOSCO has developed a code of conduct for CRAs, and published several studies on its implementation. ${ }^{44}$

\section{Basel I I Capital Accords Would Have a Limited Effect on the Subprime Boom and Crisis}

Basel II was not in effect in the U.S. during the subprime boom, and it does not apply to non-bank lenders. Basel II Pillar 1 capital standards primarily affect 
mortgage lending in three respects: 1) lower risk weights for mortgages retained on bank balance sheets in countries where lower losses can be demonstrated, 2) lower risk weights for loans backed by mortgage default insurance, and 3) specific capital requirements for bank investments in mortgage-related securities. Pillar 3 of Basel II requires banks to provide qualitative discussions of securitizations and off balance sheet exposures, representing a limited improvement, given the qualitative nature of the requirements (IMF, 2008,). Pillar 2 requires supervisors to review the quality of these disclosures. The more advanced Basel II internal ratings based standards will be implemented between 2008 and 2011 by large, internationally active banks in the U.S., and so were not in effect during the growth of subprime lending at the beginning of the decade. ${ }^{45}$ The Basel II accords do not apply to non-bank lenders, to investment banks, or to CRAs.

\begin{abstract}
Although the U.S. has arguably one of the most transparent financial markets in the world, market discipline was of little use in reining in the subprime boom or preventing the crisis. Offering documents provide summary descriptions of key collateral performance indicators ${ }^{46}$ Risky subprime-backed securities were sold only to sophisticated institutional investors, not to individuals. Investors depended excessively on agency ratings for assurance that the bonds would pay, rather than conducting their own analysis. Investors apparently felt that the yields offered by subprime securities compensated for the risks they were taking (J affee, 2008). While they are a crucial part of efficient and stable financial systems, market disclosures were insufficient to prevent subprime excesses. The short term earnings incentives from fees and the strong demand for higher yield paper created a race to the bottom with respect to credit underwriting rules and leverage. Individual market participants maximized their short term individual utility in the form of fee income and issuance volume, while ignoring the longer term system-wide effects of higher defaults and leverage.
\end{abstract}

\title{
Lenders and CRAs abandoned industry best practice for the employment of
} econometric models for default and loss. The reliance on rating agency default and loss models for pricing and trading subprime securities has been a central controversy in the subprime crisis (IMF, 2008, PWG, 2008, Jaffee, 2008). At the beginning of the boom, subprime lending was a new asset class, and so the rating agency and lender default models only had performance data for a limited population of borrowers during a property boom, when rising collateral values masked credit risk. Basel II will permit 
sophisticated banks in developed markets to set reserves and capital for retained mortgages using historical statistics on their expected default frequency and loss given default. But this methodology can be reasonably extended only to markets that have developed data sets that span full credit cycles. ${ }^{47}$ Were the Basel II standards for internal ratings applied to subprime lending, lenders would have been required to show that they had at least five years of data on the performance of subprime loans made to target lending groups before they would receive preferential capital treatment. In contrast, the CRAs began giving triple- A ratings to pools of option ARM loans in 2000, even though there had been few such loans made to moderate income subprime borrowers. The inaccuracy of rating agency subprime default expectations only highlights the importance of moving carefully to the adoption of statistical models in markets that lack historical data.

To the degree that Basel II raises the cost of holding risk on a bank's balance sheet, banks will look for ways to shift risk to where it is cheaper to hold it. U.S. and international accounting standards permitted the use of off-balance sheet treatment of large financial operations with limited transparency to investors and regulators (IMF, 2008). The use of lightly-regulated non-bank lending subsidiaries and the creation of off-balance sheet SIVs reflects relative capital and disclosure costs. Basel II addresses the use of SIVs and securitization with its Pillar 1 rules for true sale and recourse, and Pillar 3 rules for qualitative disclosure of securitization transactions.

\section{Observations and Recommendations for Emerging Markets}

Broadly speaking, there has been no subprime mortgage lending in emerging markets. Instead, mortgage lending is typically made on conservative terms to middle and upper income households employed in the formal sector:

- Most emerging market households handle their economic lives in cash, lack bank accounts, and few have access to credit. Bank branches are concentrated in wealthier urban areas and their products are targeted at upper income earners. Surveys in India, Pakistan, Colombia, and Mexico show between 170 and 440 savings accounts per 1,000 people, versus between 970 and 2,400 per 1,000 people in developed countries. Loan accounts in India, Bangladesh, and Pakistan range 
between 30 and 80 per 1,000 people, versus between 250 and 775 in developed countries. $^{48}$

Consumer finance markets are relatively small in emerging markets. Consumers tend to carry less debt than do their developed country counterparts, and they often prepay mortgage debt as rapidly as possible. In recent years, the household debt-toGDP ratio for European accession countries was 12 percent, Thailand's was 29 percent, those of Hong Kong, South Korea and Malaysia, ranged between 60 and 65 percent, and the U.S. rose to 107 percent (Fitch, 2007, BIS, 2008, Coricelli, et al, 2008). Thirty- nine percent of Thailand's Government Housing Bank mortgage borrowers are civil servants, and 50 percent are employed in the formal private sector (Fitch, 2007). Partial prepayments in Colombia in the early part of the 2000s ran at 8 percent per year, as consumers sought to retire inflation-indexed mortgages as quickly as possible. ${ }^{49}$

- Given the overall lack of access to credit, and the relatively high cost of registering and enforcing a mortgage lien, emerging market banks have been slow to move down market with mortgages. Mortgage lending is typically less than 20 percent of GDP in emerging markets, while it ranges between 40 and 100 percent of GDP in developed countries. (Chart 5.)

Mortgage credit in emerging markets carries relatively low LTVs and short maturities. LTVs in China, Hong Kong, Indonesia, and Korea range between 70 and 80 percent (Zhu, 2006). LTVs at origination in Mexico range between 60 to 80 percent and only recently were permitted to rise to 90 percent. ${ }^{50}$ Loan maturities for nominal local currency loans in Mexico, Peru, and China run typically between 10 and 15 years. ${ }^{51}$

- Since the macroeconomic crises of the late 1990s, low interest rates, low inflation, and financial sector reforms have caused mortgage default rates to fall dramatically. In Thailand, NPLs on housing loans dropped from 30 percent in 2000 to 7.6 percent at the end of 2006 (Fitch, 2007). Default rates in Mexico fell from 33 percent in 1998 to 3.2 percent in 2005 (BBVA, 2008). In India, 90 day delinquency rates range between 2.7 and 6.8 percent, as a function of the LTV ratio (Government Housing Bank). 
- Many emerging mortgage markets lack long term funding tools such as covered bonds and securitization that permit lenders to extend the maturity of their loans. In East Asia, the first MBS were issued in China, Hong Kong, and Singapore within the past four years (BIS, 2006). Within Latin America, active large scale mortgage securitization markets have emerged only in Mexico, Colombia, and Chile (BBVA, 2008), and only Chile has a widespread covered bond market.

Chart 5

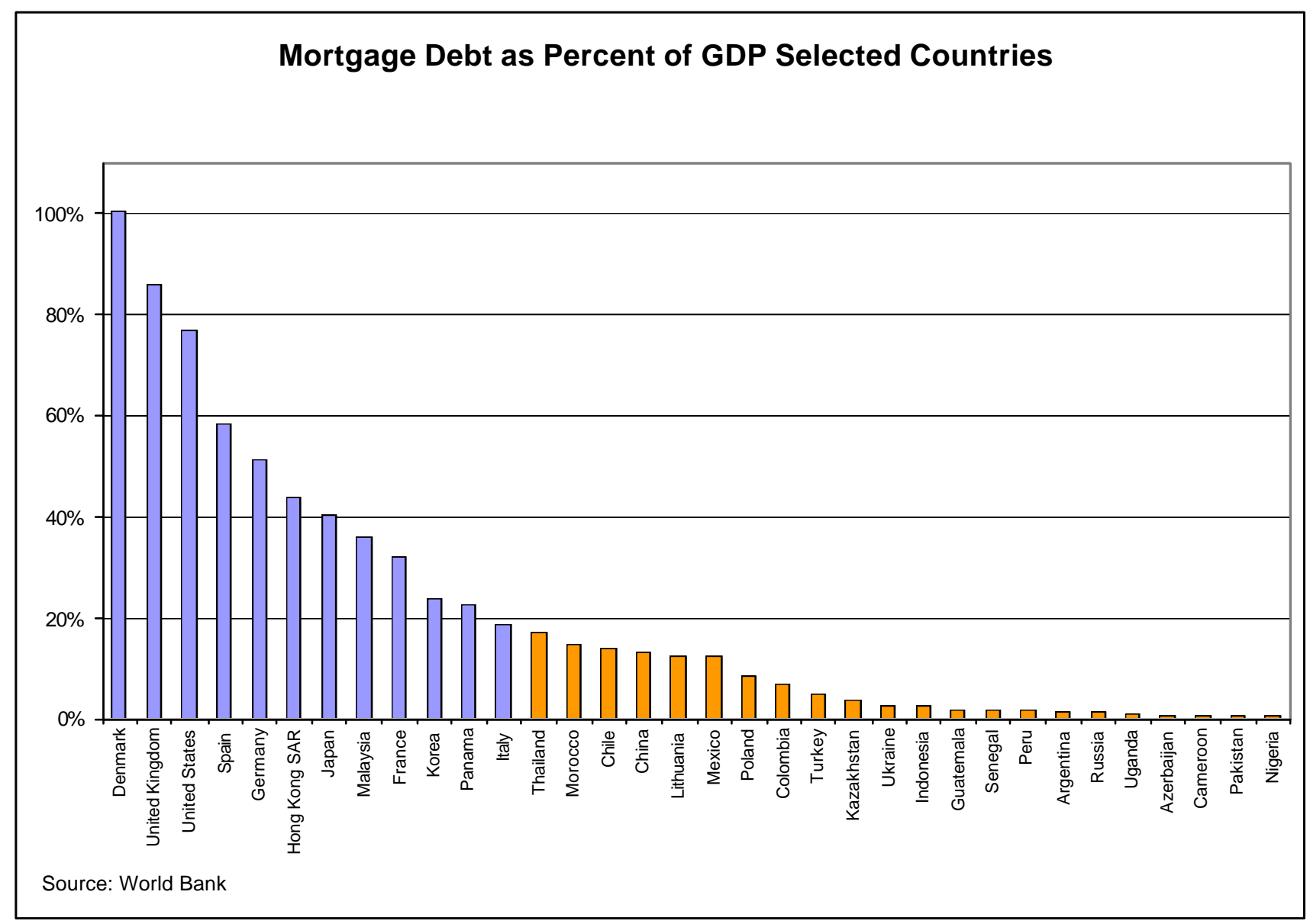


Emerging financial markets have been damaged by losses from opaque offbalance sheet entities. Weaker reporting regimes reduce market discipline. For instance, Guatemala's Bancafe failed in 2006 as a result of levered investments by an offshore unit based in Barbados (Fitch, 2007). In transition countries, including Russia and Poland, domestic legal shortcomings have led banks to securitize leases and mortgages using offshore vehicles under the laws of other countries, such as Great Britain and the Netherlands. To the degree that any of these securitizations permit recourse to the issuing institution, the domestic financial systems may bear more risk than is widely understood.

Smaller economies have relied on foreign capital to fund growth in domestic financial markets. These countries have suffered in the international credit crunch, as international investors fled to high quality government bonds from large economies, including Europe, and somewhat ironically, the United States. Kazakh banks incurred external debt worth 46 percent of GDP by the end of June 2007, then saw their access to international capital markets curtailed two months later as a result of the international credit crunch. The government has had to tap its reserve funds to help banks to meet foreign currency commitments and maintain liquidity in the banking system. Other countries without Kazakhstan's oil wealth lack the capacity to compensate against such exposures (Fitch, 2007).

Housing policies for low and moderate income groups should not be excessively weighted towards owner-occupied solutions. Households with low and uncertain incomes may be better off renting than owning housing that meets standards for health and safety. If subsidies are provided, they should be available for either ownership (for example with down payment assistance) or rental (for instance with rental vouchers), and in either case for new or used units. There should be balanced protections in law for mortgage lenders and borrowers, and for rental landlords and tenants. Tax treatment should not unduly favor owning or renting.

The challenge for emerging markets is to increase access to housing finance for moderate and low income households while maintaining strong standards for credit risk management. Governments can reduce the cost of housing by increasing efficiency in land markets. Banks may increase the supply and maturity of mortgages by financing themselves with covered bonds or by securitizing portfolios. They may extend 
credit to lower income households by employing more labor-intensive microfinance management methods. Emerging market lenders can extend credit to moderate income households using alternative documentation methods and credit scoring technology while maintaining strong credit underwriting standards.

\section{Primary Market Practices}

Maintain standards for risk-based pricing, credit underw riting, capital and reserve retention during the full real estate market cycle. While market disclosures are crucial to the operation of efficient and fair markets, they proved inadequate to prevent the subprime crisis. When a market boom creates disincentives to maintain origination standards, financial regulators need to enforce credit underwriting and risk management requirements for all lenders and for capital market participants. Lenders should avoid excessive reliance on credit scores, rather use them as a complement to traditional underwriting methods. Basic elements for mortgages include an equity contribution by the borrower, verification and documentation of willingness and ability to pay, and industry standards for appraisal methodology.

Evaluate mortgage credit ris $\mathrm{k}$ in terms of the borrower's income, not the value of the property. Even though mortgages are secured with a lien on a house, collecting mortgage debt by foreclosing on the house generally results in a loss to the lender, especially when house prices are flat or falling. However, as the recent boom persisted, lenders came to rely increasingly on expected house price increases rather than borrower income. At the same time, lenders became increasingly tolerant of very high loan- to value ratios (LTVs) without income verification or credit enhancements. (Demyanyk and Van Hemert 2007, Gramlich 2007, various OCC guidances.)

The primary means to evaluate the capacity to pay is the borrower's debt-toincome ratio. It may be expressed either in terms of monthly housing payment to monthly income gross of taxes, or total monthly obligations (mortgage and other consumer debt) divided by monthly gross income. For prime mortgage loans in the U.S., the standard for mortgage debt to gross income is 28 percent for monthly housing payment to gross income and 36 percent for total debt obligations to gross income. ${ }^{52}$ For subprime lending, the mortgage payment to income ratio was allowed to range much 
higher, averaging 41 percent in 2006, and in some cases exceeding 50 percent (Fitch, 2007).

To evaluate the debt to income ratio adjustable rate mortgages (ARMs), the lender should estimate the affordability at a fully-adjusted rate of interest. This requires assessing at the time of origination the borrower's ability to pay at the fully indexed rate, ignoring any artificial discounts and taking into account predictable near term adjustments. In originating 2/28 and 3/27 ARMs, debt-to-income analysis was generally done only with the teaser rate, and no evaluation of the affordability of the fully adjusted rate was conducted..$^{53}$ In many cases, there was an expectation at the time the loan was made that the borrower would refinance to another, better loan before the adjustment point was reached. ARMs with periodic and lifetime caps on rate adjustment can be a useful product for lower and moderate income borrowers when correctly underwritten.

Allow flexibility in sound credit management practices while increasing access for low and moderate income borrowers. Lenders should be required to document borrower income, but be allowed flexibility with respect to the means by which informal income earners establish their ability to pay. This can include structured savings programs, rent and utility receipts, and co-signatures by friends and family members. Mexican lenders have developed proprietary credit scoring systems. Half of the mortgage lending in recent years funded by Mexico's Federal Mortgage Company (known by its Spanish language acronym SHF) via non-bank lenders has reached households earning between the median and $70^{\text {th }}$ percentile, a significant improvement over previous years, when most lending was to households in the $70^{\text {th }}$ percentile or higher. As much as 15 percent of non- bank lending has gone to informal sector workers. SHF also supports microfinance for housing and subsidy programs for households earning less than the median. ${ }^{54}$ Financial products such as mortgage default insurance have contributed to the stable extension of mortgage credit to moderate income households in Mexico, Hong Kong, the U.S., Canada, and other countries.

Prepayment fees should be limited to the actual financial cost of refinancing incurred by the lender or investor. Yield maintenance fees are common in many countries that feature long term fixed rate loans. 55 These fees eliminate the financial gain for the consumer from exercising the prepayment option. In some countries 
contractual limits on prepayment are the norm. Any such fees or limitations should be clearly disclosed to the borrower. Prepayment fees should not exceed the mark-tomarket loss that the lender incurs as a result of prepayment.

Set LTV requirements in terms of the local history of house price movements and prevailing foreclosure costs. Authorities should look at the history of house prices in their markets to see how volatility is likely to affect the equity position of a high LTV Ioan. Countries with higher volatility will want to set the LTV standard lower than others. For instance, if house prices have a substantial likelihood of dropping 5 percent over a given 5 year period, then 95 LTV loans would be inadvisable. Rapidly urbanizing markets, such as China and Mexico, where valuations are based largely on new construction, should require lower LTVs. (In fact, China has restricted LTVs to 65 percent in its more overheated cities.) In more mature markets, with a longer history of trading of both new and used housing, higher LTVs may be acceptable. Likewise, longer or more uncertain foreclosure periods or higher costs should drive lower LTV norms.

As property prices rise, discount the appraised value of the collateral property. In rapidly rising markets, authorities should require lenders to discount the appraised valued of properties. Such a discount is embedded in German regulation. Mortgage lenders are permitted to lend on 90 percent of the appraised value (VDP 2006). Owneroccupied properties may be valued in relation to comparisons to prices of five similar properties, subject to a deduction of 10 percent as a "safety margin." Regulators could go beyond 10 percent in particularly volatile markets.

Require lenders to counter-cyclically adjust loss provisions to reflect changing property prices. As property prices rise, regulators can require lenders to set aside more for expected losses from defaults. Spain has had such a dynamic provisioning rule in effect since 2000. Banks are required to complement the standard 0.5 percent specific provision for expected losses and with an additional amount that reflects "latent global losses." Each quarter, banks set the statistical provision either in relation to their statistical default experience in each asset class, or if they lack such data, in terms of fixed percentages set by asset class in the regulation. The additional statistical provision for mortgages with an LTV of 80 percent or less is 0.1 percent (Bank of Spain, 1999). As described by the Bank of Spain, 
"In good times the specific provision is low and the statistical provision is positive. However, in a slowdown, as impaired assets rise, the specific provision requirements increase and the statistical provision becomes negative. This means that the statistical fund (accumulated in previous years) starts being used, its proceeds (the difference between the latent risk and the specific provision) being credited to the profit and loss account. Therefore, thanks to the mechanism of the statistical provision, the burden of credit risk on the profits of banking institutions is better spread over the cycle and more in accordance with the evolution of expected losses."

As a result of the dynamic provisioning rule, general provisions at Spanish banks rose by roughly 250 percent between 2000 and 2007, while specific provisions remained largely unchanged. The doubtful assets coverage ratio at Spanish banks averaged over 200 percent of bad loans at the end of 2007, versus a European Union average of 60 percent (Fernández de Lis, 2008). Given the boom in Spanish property prices, 12.2 percent per year between 2000 and 2005, the additional provision represents a useful cushion against a possible market decline (van den Nord, 2006).

Create a public data base on property prices, mortgage interest rates, mortgage lending volumes, and mortgage loan performance. Confidence increases when investors are aware of price movements and cycles. Regulators and lenders in middle income countries have only recently begun to keep such data. The IMF and World Bank have jointly developed recommended indicators for real estate markets as part of their work on financial stability monitoring. These include separately reporting real estate lending by types of financial institutions, and creating real estate price indexes. ${ }^{56}$ Central banks, financial regulators, statistical agencies, and the private sector should collaborate to create real estate information centers that gather and report basic data on real estate markets and financial activity. Such data enables property appraisers to provide more accurate estimates of market value. Thailand created such a center in 2004. ${ }^{57}$ Lenders and mortgage insurers in Mexico have reliable data from the beginning of the 2000s, when the public MI product was restructured, and a few mortgage lenders began to securitize their portfolios, but this data reflects a period of rising house prices, similar to the boom experienced in the U.S. in the same period. In Colombia, data exists for mortgages that survived the crisis of 1998 that were securitized, and for loans that have been originated more recently, as the market has rebounded. But these time 
periods represent separate paradigms in terms of market circumstances, and do not lend themselves easily to sweeping conclusions about default probability or loss given default. In China, mortgages have been made only since the reforms of 1998, in a real estate boom in coastal cities, and loan data has not been consistently gathered across the industry. In many other emerging markets, lending is much less widespread, and no industry-wide data is collected at all.

\section{Prudential Regulation of Non-Depository Lenders}

Ensure that all lenders have clear incentives to mitigate credit risk. As they grow in importance in any economy, NBFIs should be subject to prudential supervision. The lack of regulation of U.S. non- bank mortgage lenders, off-balance sheet SIVs, and hedge funds led the system to shift capital to them during the subprime boom. As Basel II is implemented, banks will have a greater incentive to lay risk off to third parties. National authorities are now considering how to avoid regulatory arbitrage among different types of financial institutions (IMF, 2008). Supervision of non-bank mortgage lenders could be less intrusive than that of depository institutions. Rules could include less frequent examinations for safe lending practices, and a minimum reserve or capital rule that is linked to a stricter requirement to repurchase poorly underwritten mortgages. For example, such a requirement could extend two years after origination and cover a larger volume of potential repurchases than has been required in the U.S. Lenders could be required to retain a portion of the subordinate bonds issued as part of seniorsubordinate structures. Non-bank lenders could be required to realize fee income over a period of time and as a function of the performance of the loans rather than at the time the loan is originated.

I mplementation of Basel II should reflect local market conditions. Risk weights for mortgage lending should reflect local experience with default and foreclosure costs. Preferential weights under either the standardized or internal ratings based approach should reflect a long history of industry-wide data on mortgage performance. If it is not possible to demonstrate that mortgage lending is safer than uncollateralized lending, then it should carry a capital risk weight that reflects that risk. The promise of a lower risk weight can compel the reform of legal processes for contract enforcement. 
The institutional structure for regulation should be unified and cohesive. Every country has to work with its own history and political forces in structuring its regulatory system. No one would set out to design the system that the U.S. has today. Many countries have been moving towards a unified prudential regulator, along the lines of the United Kingdom's Financial Services Authority. Whatever the structure, there should be clear responsibility for a given economic activity, regardless of the institution that is licensed to provide it. The capital and risk management requirements for all market participants should be harmonized to minimize incentives to shift risk to one institution or another.

\section{Provide Robust Links to Capital Markets}

Capital market funding can take at least two forms, securitization and covered bonds, and many countries have created liquidity backstops. Diversity in funding instruments and funding sources provides lenders with choices for managing capital in the context of term matching, credit risk, and operational risk. Many countries have developed securitization or covered bonds along with second tier liquidity facilities that allow lenders to keep mortgages on balance sheet. ${ }^{58}$ Spain has developed active markets with covered bonds and securitization as capital market tools.

\section{Capital market funding can be developed in the context of robust market practices. Authorities should assure that at some stage of the securitization process, at least one participant besides the loan originator reviews the documentation of loans in the collateral pool and assures adherence to a minimum level of credit documentation. This may be the investment bank that arranges the securitization, the rating agency, a mortgage default insurer, or a special auditor. Any third party reviewer should have clear mandate, incentive, and accountability that is driven by a long term perspective to maintain loan quality rather than a focus on production volume. Third party private or public sector insurers can provide the basis for an investment grade rating when data is lacking, as has frequently been the case. ${ }^{59}$}

The emphasis on market discipline of Basel II Pillar 3 should be an important means to limit risk taken by credit risk transfer mechanisms. Regulators need to develop clear and comprehensive rules for disclosing the terms and extent of credit risk transfers and subsequent recourse or liquidity obligations, and overall risk exposures. 


\section{Credit Rating Agencies should be subject to rules for disclosures for their}

activities. Many countries have a licensing requirement and at least a nominal oversight function for CRAs. Competition issues associated with CRAs are more pronounced in emerging markets, particularly small ones with small and illiquid capital markets. In many emerging markets, only one of the three major international CRAs are active, often via contracts with domestic economic consulting firms, or via offices in nearby countries. ${ }^{60}$ These local firms typically lack expertise in arcane topics like structured finance.

As the largest CRAs have already agreed, they should adhere to the International Organization of Securities Commissions (IOSCO) code of conduct. Authorities could establish in regulation the requirement that CRAs adhere to the IOSCO code of conduct. Given the role of agency ratings in regulatory standards like the Basel capital accords, authorities should distinguish the role of CRAs from that of financial journalists. Unsolicited ratings should be prohibited. CRAs should be required to provide clear disclosures of the methodology, data, and rationale behind ratings, upgrades, and downgrades. CRAs should be discouraged from rating structured transactions in the absence of data on the performance of the collateral. In new lending and securitization markets, ratings for securitized collateral that has a limited performance history can be supported by default and loss estimations from other countries, and supported by third party credit enhancements. Alternative models for ratings agency fees should be explored, including having investors (rather than investment banks) pay to have securities rated. If investors choose to pay for the rating of the securities, they should be warned when there is insufficient information upon which to make an informed judgment.

\section{Financial Reporting}

While stronger financial reporting and disclosure standards were not sufficient to prevent the subprime crisis, they remain crucial for improving efficiency in emerging mortgage markets. The failings of the New Century auditor and the inadequacy of reporting of off- balance sheet entities in the case of Sachsen LB serve to highlight the importance of reporting in all markets. To the degree that lenders securitize portfolios, particular attention has to be paid to the nature of transactions, whether they meet standards for true sale of the collateral. If issuers retain exposure to 
the transaction, the nature of the risk retained should be disclosed clearly, and the institution should hold reserves and capital commensurate with the risk.

\section{Consumer Protection in Mortgage Lending ${ }^{61}$}

Access to finance has to be balanced with appropriate products and consumer protections. Moderate and lower income households are able to pay for appropriately designed mortgages. It is unwise to offer mortgage loan products with risky adjustment capacities to households that lack the resources to manage the risk. This is particularly the case for households with limited education and financial training that are more prone to make less rational choices in the face of complexity. Rental housing and carefully targeted subsidies are appropriate for the lowest income groups. As a result of stronger underwriting the U.S. public insurance program FHA has experienced much less deterioration in its performance than have subprime loans. Clear disclosure and suitability rules should be an important part of mortgage lending.

Consumer protection is particularly important for mortgage lending. A house purchase is the largest, most highly leveraged, and most complex financial transaction most consumers will ever undertake. A mortgage creates the burden of sizeable payments over extended periods, coupled with the risk of losing the primary residence should the burden prove too great. Housing finance contracts contain many financial options for the consumer (e.g., early repayment) and the lender (e.g., assignment or sale of the loan, rate adjustment), the values of which are extremely sensitive to changing market environment and the outcomes of which may impose additional risk on the consumer.

Mortgage borrowers often fail to understand the terms of complex mortgages. In a 2007 study of mortgage borrowers, the Federal Trade Commission (FTC) found that both prime and subprime borrowers failed to understand the costs and terms of their loans using existing disclosure forms (Lacko, Pappalardo, 2007). The behavioral finance literature shows that individuals often make irrational choices in the face of complexity. ${ }^{62}$ When they read loan documentation, many borrowers lack the financial training to understand the risks of complex adjustable loans. Some part of weak subprime underwriting resulted from inaccurate or incomplete disclosures to borrowers. 


\section{Consumer protection rules should contribute to improved efficiency of the}

mortgage market, especially by addressing the market failures that lead to reduced levels of competition, high costs of loans, or the exclusion of consumers. The most important failures arise from information asymmetries between lenders and consumers; the heterogeneity of consumers with respect to their financial education, gender, race, and other factors; and transaction-cost asymmetries, which limit the ability of consumers to react to lender action; e.g., to an interest rate increase.

\section{Consumer protection rules should contribute to market stability and social} protection: stability in the sense of avoiding over-indebtedness of borrowers, with its consequences for the solvency of lenders and systemic risk for the financial sector. Social protection is relevant in the sense of mitigating individual hardship caused by mortgage market outcomes.

\section{Consumer protection rules should provide for clear disclosures and fair} competition, and should prohibit abusive charges. Predatory lending can have a much broader reach than the individual borrower. In the U.S., risky subprime lending practices could have been restricted much earlier by tightening existing rules on nonbank lenders. Arguably, this would have reduced the scale of the crisis. As they work to increase access to finance, authorities in emerging markets should establish clear and workable rules for disclosing the complete costs and risks of mortgage borrowing, and to protect consumers from unscrupulous lenders. Examples of disclosures include Mexico's transparency law and the United Kingdom's disclosure regulation (Box 1.).

Consumer disclosures are important in emerging markets that issue price level adjusting mortgages, where the principal amount varies with inflation. ${ }^{63}$ Credit risk can rise if mortgages and salaries are not indexed in the same fashion. Clear disclosures and explanations are required to make sure that the borrower understands how her mortgage payment may change over time. 


\section{Box 1: Mexico's Law on Mortgage Disclosures}

Prior to the financial crisis of 1996, Mexican banks provided a wide variety of loan products, some with aggressively low initial "teaser" interest rates. The combination of such teaser rates with inflation-indexed principal led to a sharp rise in defaults when inflation and interest rates both rose quickly during the crisis. As a step towards restoring consumer confidence in the mortgage market, the government passed the Federal Law on Transparency and Promotion of Competition in the Guaranteed Credit Market of 2002 that standardized consumer disclosures for mortgage lending. The law's mandates include:

- Lenders must disclose the effective interest rate, taking into account the total cost of credit, including interest, all fees and charges.

- A standard for the disclosure of contract terms, minimum contents of contracts.

- Loan offers must be binding for a period of 20 days.

- Appraisal standards and authorization of appraisers.

The Federal housing finance agency, Sociedad Hipotecaria Federal (SHF), provides monthly comparative loan offer information to consumers. Lenders provide indicative loan terms and payments in clear and simple charts that are publicly displayed on loan office walls.

\section{The United Kingdom's Disclosure Regulation}

Mortgage lenders became subject to regulation by the Financial Service Authority (FSA) in 2004. FSA rules for mortgage lending are listed in the Mortgage Conduct of Business rulebook (MCOB), a key requirement of which is the provision of standardized disclosure documents to consumers. These two documents, the Initial Disclosure Document (IDD) and the Key Facts Illustration (KFI), aim to help consumers better understand the services on offer and the features and risks associated with mortgages that they take out, including the affordability risks. The provision of these documents is mandatory. The FSA also produce a fact sheet that is not mandatory for lenders to distribute - "You 
can afford your mortgage now, but what if...?" - that is designed to inform consumers of the affordability risks of taking out a mortgage.

The IDD provides information on the products that the lender offers, the agency that regulates the lender, contact information in case the consumer wishes to complain about her treatment by the lender. The KFI illustration details all of the interest costs and other charges that will be levied with the actual loan for which the consumer is applying. The fact sheet on affordability discusses the risks of mortgage lending for the consumer: the possibility of job loss, the dependence of adjustable rates loans on the interest rate policies of the central bank, and the types of fees that lenders may charge.

The FSA has followed up the creation of these regulations with studies to determine the effectiveness of the disclosure documents on actual consumers. The overall results have been positive, although less well educated consumers had trouble understanding some of the percentage costs and tabular information that they disclosures provide. The FSA stresses that these documents should form the basis of a conversation with the consumer that permits them to understand the complete costs and risks of the loan. 


\section{Bibliography}

Agarwal, Sumit, Brent Ambrose, Souphala Chomsisengphet and Anthony B. Sanders, 2008. "Subprime Lending and Default: The Impact of Loan Concentration," Working Paper, Arizona State University.

Aharony, J oseph, Anthony Saunders, Itzhak Swary. 1988. "The Effects of DIDMCA on Bank Stockholders Returns and Risk" J ournal of Banking and Finance 12. 317-331. North- Holland

Akerlof, George A. 1970. "The Market for "Lemons": Quality Uncertainty and the Market Mechanism" The Quarterly Journal of Economics, Vol. 84, No. 3 August., pp. 488-500.

André, et al. 2006. "Recent House Price Developments: The Role of Fundamentals", OECD Economics Department Working Papers, No. 475, OECD Publishing.

Ashcraft, Adam B., and Til Schuermann. 2007. "Understanding the Securitization of Subprime Mortgage Credit," Federal Reserve Bank of New York.

Avery, Robert B. Kenneth P. Brevoort, Glenn B. Canner, 2007. "The 2006 HMDA Data," Federal Reserve Bulletin v93 September 12.

Bair, Sheila. 2001. "Mortgage Reform and Predatory Lending: Addressing the Challenges," Statement by Treasury Assistant Secretary Sheila Bair

Bernanke, Ben S. 2004. "Remarks by Governor Ben S. Bernanke At the meetings of the Eastern Economic Association," Washington, D.C., February 20.

http: //www. federalreserve.gov.

Berson, David W., 2006 "Challenges \& Emerging Risks in the Home Mortgage Business", Presentation to The National Housing Forum, Office of Thrift Supervision, Washington, DC, December 11.

Bureau of Economic Analysis. 2007. “Table 1.1.2. Contributions to Percent Change in Real Gross Domestic Product", www.bea.gov. 
Butera and Andrews. 2007. "State and Local Predatory Lending Laws (As of 01-22-07)", mimeo.

Calhoun, Charles. 2005. "The Hidden Risks of Piggyback Lending", June memo.

Camerer, Colin F. 2003. "The behavioral challenge to economics: Understanding normal people", Federal Reserve of Boston.

Case, Karl E. and Robert J. Shiller. 1989. "The Efficiency of the Market for Single Family Homes," The American Economic Review 79:1, 125- 37.

Caskey, John P., Clemente Ruíz Durán, and Tova Maria Solo, 2006. "The Urban Unbanked in Mexico and the United States," World Bank Policy Research Working Paper 3835. February.

Center for Responsible Lending, 2008 "A Snapshot of the Subprime Crisis," available at http: // www. responsiblelending.org/issues/mortgage/quick-references/a- snapshot- ofthe-subprime.html\#_edn29

Chiquier, Loic, and Michael Lea. 2008. "Housing Finance Policy in Emerging Markets," World Bank Group, forthcoming.

Chomsisenghphet, Souphala and Anthony Pennington-Cross. 2006 "The Evolution of the Subprime Mortgage Market," Fed. Reserve Bank of St. Louis Review at 34 J anuary/February.

Clauretie, Terrence M., and Thomas N Herzog. 1990. "The Effect of State Foreclosure Laws on Loan Losses: Evidence from the Mortgage Insurance Industry." J ournal of Money, Credit and Banking, vol. 22, issue 2, pages 221-33.

Common Cause. 2007. "Ask Yourself Why Mortgage Foreclosure Rates are So High," Celia Wexler.

Demyanyk, Yulia, and Otto van Hemert. 2007. "Understanding the Subprime Mortgage Crisis," Federal Reserve bank of New York. 
Department of J ustice. 2008. "The Attorney General's 2007 Annual Report To Congress Pursuant To The Equal Credit Opportunity Act Amendments of 1976," April

Djankov, Simeon, Rafael La Porta, Florencio Lopez-de-Silanes, and Andrei Shleifer. 2002. "Courts: The Lex Mundi Project." NBER Working Paper Series, Working Paper 8890.

Duebel, Joachim. 2006. "Consumer Information \& Protection in Mortgage Finance", Presentation World Bank Group Housing Finance Conference.

Dugan, John C. 2007. "Remarks by John C. Dugan Comptroller of the Currency Before the Neighborhood Housing Services of New York".

E. Scott Reckard. 2008. "Sub-prime mortgage watchdogs kept on leash." Los Angeles Times.

Edmund L. Andrews. 2007. “Fed Shrugged as Subprime Crisis Spread," Wall Street Journal

Engel, Kathleen C., and Patricia A. McCoy. 2007. "Turning a Blind Eye: Wall Street Finance of Predatory Lending," University of Connecticut School of Law, Working Paper 73

Federal Trade Commission (FTC). 2007. "Prepared Statement of the Federal Trade Commission on Consumer Protection in Financial Services Before the House Committee on Financial Services."

Federal Trade Commission (FTC). 1998. "Prepared Statement of the Federal Trade Commission by Jodie Bernstein, Director. Bureau of Consumer Protection before the Senate Special Committee On Aging on Home Equity Lending Abuses in the Subprime Mortgage Industry."

Federal Deposit Insurance Corporation (FDIC). 1997. “Financial Institution Letters Subprime Lending," FI L-44- 97. 
Federal Financial Institution Examination Council (FFIEC). 2008. Home Mortgage Disclosure Act (HMDA) Data. National Aggregate Tables. www.ffiec.gov

Federal Reserve Board. 2007. “Proposed Amendments to Regulation Z (Truth in Lending)."

Federcasa, Italian Housing Foundation. September 2006. "Housing Statistics in the European Union 2005/2006",

Fernandez De Lis, Santiago, 2008. "New Regulatory Challenges for Mortgage Markets: Lessons from Spain," presentation the World Bank Conference, Housing Finance in Emerging Markets: Is the Expansion Affected by the Sub-Prime Crisis? May.

Fitch Ratings. 2007. “U.S. Subprime Rating Surveillance Update, Glenn Costello Managing Director," presentation.

Fitch. October 2006. "Republic of Guatemala Intervention of Banco del Café (Bancafe)". Foote, Christopher L., Krisopher Gerardi, Lorenz Goette, and Paul S. Willen. 2008. "Subprime Facts: What (We Think) We Know About the Subprime Crisis and What We Don't," May, Federal Reserve Bank of Boston Public Policy Discussion Papers, No. 08-2.

General Accounting Office (GAO). 2004a. "Consumer Protection Federal and State Agencies Face Challenges in Combating Predatory Lending," GAO-04- 280

General Accounting Office. 2004b. "Financial Regulation Industry Changes Prompt Need to Reconsider U.S. Regulatory Structure." GAO-05-61

Gensler, Gary. 2000. “Treasury Under Secretary Gary Gensler House Banking And Financial Services Committee."

Glaeser, Edward L., and J. Shapiro. August 2003. "The Benefits of the Home Mortgage Deduction." Tax Policy and the Economy, 17, pp. 37-82

Glaeser, Edward L., J oseph Gyourko, and Raven E. Saks. 2005. “Why Have Housing Prices Gone Up?" American Economic Association Papers and Proceedings, May, 2005. 
Gramlich, Edward M. 2007. "Subprime Mortgages, America's Latest Boom and Bust," Washington, Urban Institute Press.

Green, Richard K., Stephen Malpezzi and Stephen K. Mayo. 1999. "Metropolitan-Specific Estimates of the Price Elasticity of Supply of Housing, and Their Sources.", University of Wisconsin James A. Grasskamp Center for Real Estate Working Paper 99-16.

Herring, Richard and Susan Wachter. 1999. "Real Estate Booms and Banking Busts: An International Perspective", working paper 99-27, Wharton School Financial Institutions Center

Herring, Richard, and Susan Wachter. 2002. "Bubbles in Real Estate Markets", memo, Federal Reserve Bank of Chicago and World Bank Group

Housing and Urban Development, Department of (HUD), and Department of the Treasury (Treasury). 2000. "Curbing Predatory Home Mortgage Lending."

http://www.huduser.org/publications/hsgfin/curbing.html

Internal Revenue Service. 2007c, "Home Mortgage Interest Deduction," Publication 936, Cat. No. $10426 \mathrm{G}$

Internal Revenue Service. Fall 2007a, “Individual Income tax Returns, 2005," Statistics of Income Bulletin.

Internal Revenue Service. Fall 2007b, "Tax-exempt Bonds, 2005" Statistics of Income Bulletin.

International Monetary Fund. April 2008. "Global Financial Stability Report, Containing Systemic Risks and Restoring Financial Soundness."

International Monetary Fund. March 2006. Financial Soundness Indicators Compilation Guide.

Ip, Gregory and Damian Paletta. 2007. "Regulators Scrutinized In Mortgage Meltdown," Wall Street Journal 
Jaffee, Dwight M. 2008. “The U.S. Subprime Mortgage Crisis: Issues Raised and Lessons Learned," Draft Date: April 7, 2008, Prepared for the Commission on Growth and Development and the World Bank http://www.growthcommission.org/

Jappelli, Tullio, Marco Pagano, and Magda Bianco. 2002. "Courts and Banks: Effects of Judicial Enforcement on Credit Markets," Working Paper No. 58, Centre for Studies in Economics and Finance, University of Salerno

Lacko, James, and Janis K. Pappalardo. 2007. "Improving Consumer Mortgage Disclosures, An Empirical Assessment of Current and Prototype Disclosure Forms," Federal Trade Commission Bureau of Economics Staff Report

Lax, Howard, Michael Manti, Paul Raca, and Peter Zorn. 2004. "Subprime Lending: An Investigation of Economic Efficiency," Housing Policy Debate, Volume 15, Issue 3.

Leamer, Edward E. 2007. "Housing is the Business Cycle", National Bureau of Economic Research Working Paper 13428

Leventis, Andrew. 2007. "A Note on the Differences between the OFHEO and S\&P/CaseShiller House Price Indexes," Office of Federal Housing Enterprise Oversight

Mian, Atif and Amir Sufi. 2008. "The Consequences of Mortgage Credit Expansion: Evidence from the 2007 Mortgage Default Crisis," January, http://ssrn.com/abstract $=1072304$

Missal, Michael J. 2008. "Final Report of Michael J. Missal Bankruptcy Court Examiner." United States Bankruptcy Court for the District Delaware. In re: New Century TRS Holdings, Inc. A Delaware Corporation, et al, Debtors.

Mortgage Bankers Association. 2007. "Characteristics of Outstanding Residential Mortgage Debt: 2006," Research Data Note.

Mortgage Bankers Association. 2007. “National Delinquency Survey Third Quarter. National Low Income Housing Coalition (NLIHC). 2008. "2008 Advocate's Guide" 
Office of the Comptroller of Currency (OCC), etc. 1999. "Interagency Guidance on High LTV Residential Real Estate Lending".

Office of the Comptroller of Currency (OCC), etc. 2001. "Expanded Guidance for Subprime Lending Programs,"

Office of the Comptroller of Currency (OCC), etc. 2005. "Credit Risk Management Guidance For Home Equity Lending,"

Office of the Comptroller of Currency (OCC), etc. 2006. "Interagency Guidance on Nontraditional Mortgage Product Risks,"

Office of the Comptroller of Currency, Board of Governors of the Federal Reserve System, Federal Deposit Insurance Corporation, Office of the Comptroller of the Currency, Office of Thrift Supervision. 1999. "Interagency Guidance on Subprime Lending."

Partnoy, Frank. 2006. "How and Why Credit Rating Agencies are Not Like Other Gatekeepers," in Financial Gatekeepers: Can They Protect Investors? Yasuyuki Fuchita, Robert E. Litan, eds., Brookings Institution Press and the Nomura Institute of Capital Markets Research.

Pence, Karen M. 2006. "Foreclosing on Opportunity: State Laws and Mortgage Credit" Review of Economics and Statistics Vol. 88, No. 1: 177-182.

Quercia, Roberto G., Michael A. Stegman, and Walter R. Davis. 2004. "Assessing the Impact of North Carolina's Predatory Lending Law," Housing Policy Debate, Volume 15, Issue 3.

Reckard, E. Scott. March 17, 2008, "Sub-prime mortgage watchdogs kept on leash". Los Angeles Times

Reinhart, Carmen M. and Kenneth S. Rogoff. 2008. "Is the 2007 U.S. Sub-prime Financial Crisis So Different? An International Historical Comparison, "National Bureau of Economic Research, Working Paper 13761. 
Renuart, Elizebeth. 2004. "An Overview of the Predatory Mortgage Lending Process," Housing Policy Debate, Volume 15, Issue 3.

United States Census Bureau News Release, 2008. “Census Bureau Reports On Residential Vacancies And Homeownership", April 28, CB08-60

Van den Nord, Paul, 2006. "Are House Prices Nearing A Peak? A Probit Analysis For 17 OECD Countries," Organization of Economic Cooperation and Development, Economics Department Working Papers No. 488.

Verband Deutscher Pfandbreifbanken (VDP) 2006, “Regulation on the Determination of Mortgage Lending Values of Properties in Accordance with 16 pars. 1 and 2 of the Pfandbrief Act," May 12, working translation, available at http://www.pfandbrief.org/d/internet.nsf/tindex/en_lending_value.htm 
1 This paper benefitted from comments by Roberto Rocha, Bertrand Renaud, Michael Lea, Simon Walley, Roger Blood, and Loic Chiquier for which the authors are grateful. All errors remain the responsibility of the authors.

Page 61 
2 Shiller uses the Case-Shiller house price index, a repeat-sales index that samples properties from twenty metropolitan areas in the country, excluding several states.

André, et al. use the OFHEO house price index, which excludes higher priced properties, and samples from a much larger number of metropolitan areas. (Leventis, 2007).

Page 62 
3 The economic stability in Europe and the U.S since the mid-1980s (falling GDP volatility, low inflation) has been termed the "great moderation." It has been blamed in part for lowered credit risk spreads and persistent search for yield on the part of investors. (Bernanke 2004, Stock and Watson 2003). 
4 "Disaster myopia", refers to the tendency of investors to forget bad events (Guttentag and Herring, 1984). As time passes after a shock (for example, house price declines, interest rate shocks, or widespread credit defaults), lenders and investors discount the likelihood of its recurrence, and then under-price risk.

Page 64 
5 Although the definition of a subprime borrower varies from lender to lender, the following criteria capture most subprime borrowers: 1) a FICO (or credit) score of 660 or below, 2) two or more 30- day delinquent payments in the past 12 months, or one 60day delinquency in the past 24 months, 3) a foreclosure or charge- off in the past 24 
months, 4) any bankruptcy in the last 60 months, 5) qualifying debt-to- income ratios of 50 percent or higher, 6) limited ability to cover monthly living expenses.

6 An early payment default is defined as a default on a loan in any of the first three months of its life. 
$7 \quad$ Alt- A loans are extended to borrowers whose credit scores fall short of prime but are believed to be above levels associated with subprime lending.

8 See below for a discussion of tax incentives for home ownership. 
9 This comparison would be more accurate were annual cohorts of FHA-insured mortgages compared with cohorts of subprime mortgages with similar credit risk characteristics, such as LTV, debt-to-income ratio, borrower income level, geographic location, etc. However, it is clear that weak subprime underwriting has led to higher 
defaults by moderate and lower income households that FHA has lent to with greater success.

10 These institutions included the Federal Housing Administration (FHA), Fannie Mae, the Federal Home Loan Banks, and the Federal Savings and Loan Insurance Corporation.

Page 69 
In the 1930s and 1940s, the FHA played a central role in improving quality by setting minimum construction standards for the houses that collateralized mortgages that it insured. 
11 Conventional signifies loans that carry neither FHA credit insurance nor a VA guarantee.

12 Sources: HMDA data, author calculation, and Census (2008).

Page 71 
13 Access to ownership of a high quality, single family stand-alone house is a central focus of the U.S. housing policy dialogue. Since almost the entire housing stock meets construction standards, the driving determinants of ownership are the cost of urban land, required down payment, and the cost of financing. 
14 See their web sites for policy statements and executive's speeches:

www.fanniemae.com www.nar.org, www.nahb.org

15 Federal tax exemptions are available only to taxpayers who file itemized returns, where they itemize, or list separate deductions to reduce the tax paid. These include 
mortgage interest paid, moving expenses, medical expenses, charitable contributions, and a host of other expenses. To make itemization worthwhile, the reduction in taxes has to compensate for the extra effort of filing a more complicated itemized return. In $2005,35.5$ percent of taxpayers itemized, and 11.8 percent of these earned less than 
the median household income. Interest paid on mortgages represented one of the largest categories of exemptions, 32.8 percent of total deductions taken (IRS, 2007).

16 For an overview of CRA, see the Federal Reserve Board's website:

http: //www.federalreserve.gov/dcca/cra/

Page 75 
17 The 6.59 increase is the gross increase in the number of all types of owners, not just first-time owner-occupiers.

18 In the 1930s the Federal Housing Authority (FHA) explicitly referred to African Americans and other minority groups as adverse influences, and many lenders and 
insurers openly discriminated until such practices were outlawed by in 1968 by a Supreme Court decision and by the 1968 Fair Housing Act. The Community Reinvestment Act of 1977 required banks to offer products to previously underserved neighborhoods. Prosecutions of racial discrimination in lending continue under the Equal Credit Opportunity Act. See Hillier (2003), Department of J ustice (2008). 
19 See Bruskin, Sanders and Sykes, "The Nonagency Mortgage Market: Background and Overview" The Handbook of Nonagency Mortgage-backed Securities, edited by Frank J . Fabozzi, Chuck Ramsey and Michael Marz, 2000

${ }^{20}$ See Akerlof for a discussion of asymmetric information and markets for lemons.

Page 78 
${ }^{21}$ Recently, subprime prepayments have slowed dramatically compared to those before the housing market slowdown and subprime delinquency/default spike.

22 See A. Davidson, A. Sanders, L, Wolff and A. Ching, Securitization, (New York: John Wiley and Sons, 2003), Chapter 16.

Page 79 
23 “Mortgage Defaults Start to Spread: New Data Show That Nontraditional Loans Are Beginning To Haunt Borrowers With Midlevel Credit; Prime Still Fine," Wall Street Journal, March 1, 2007; Page D1 
24 "What is ALT- A... Anyway?" Andrew Davidson Company, September 2004, http://www.ad-co.com/newsletter/Sept04/Sept04.htm

25 "Defaults on Some 'Alt A' Loans Surpass Subprime Ones," Bloomberg News, July 24, 2007

Page 81 
26 "Pimco Says Subprime Woes May Spread to Alt-A, Jumbo (Update1)," Bloomberg News, March 16, 2007.

27 An adjustable- rate mortgage that allows the borrower to choose among several payment options each month. The options typically include: 1) a traditional payment of

Page 82 
principal and interest based on a set loan term; 2) an interest-only payment; and 3) a minimum (or limited) payment which may be less than the amount of interest due that month and may not pay down any principal. Borrowers that make limited payments may incur negative amortization of principal. 
28 "Stopping the Subprime Crisis," New York Times, July 25, 2007. 
http://www2.standardandpoors.com/portal/site/sp/en/us/page. article/4,5,5,1,12048359 10066.html

30 Carlyle Group's mortgage investment fund Carly le Capital Corporation failed in March, 2008.

Page 85 
31 In Mexico, non-bank lenders are called Limited Object Financial Companies, or by their Spanish acronym SOFOL. Sofols exist to make credits for cars, appliances, leases, commercial credits, and mortgages. The 2002 reform created a more flexible legal 
entity, a Multiple Object Financial company, or SOFOM. Neither SOFOLs nor SOFOMs are subject to prudential regulation.

32 On the other hand, non- bank consumer and commercial lenders are relatively common. 
33 Freddie Mac was created in 1970. Ginnie Mae securitizes mortgages that benefit from FHA mortgage default insurance.

34 For a detailed exploration of the inadequacy of such reserves, see the Final Report of the Bankruptcy Examiner in the New Century Bankruptcy case.

Page 88 
35 As defined in the U.S., there was very little subprime lending in Great Britain, and Northern Rock was predominately a prime lender. Between 2001 and 2006, about 10 percent of the loans that Countrywide originated were subprime. 
36 Access to credit should be predicated on an objective assessment of ability and willingness to pay. Prior to the passage of anti-discrimination laws and court cases in the 1970s and 1980s, racial criteria unrelated to creditworthiness played an explicit role in mortgage credit allocation in the U.S. Some racial discrimination persists. However, in 
recent years much of the racial disparity in access to mortgage lending and in mortgage costs has reflected differences in credit scores, which carry no racial information (Federal Reserve, 2007). Lower credit scores reflect broader issues of social equity, such as access to education and employment. 
37 Other responsible agencies include the Departments of Justice (DOJ ), and Housing and Urban Development (HUD). Each has brought some cases against subprime lenders for deceptive and discriminatory practices.

Page 92 
38 The Responsible Lending Act, H.R. 1295, 2005, introduced by Congressmen Bob Ney (R-OH) and Paul E. Kanjorski (D-PA) was supported by the Mortgage Bankers Association and industry lobbyists such as Butera \& Andrews. It would have reduced the interest rate threshold for defining a subprime loan, but allowed lenders to exclude 
single premium credit insurance from the costs counted towards the fee threshold. Ney was jailed in 2006 in connection with improper lobbying payments unrelated to the mortgage industry. 
39 H.R. 1182 The Prohibit Predatory Lending Act was introduced by Congressmen Brad Miller (D-NC), Mel Watt (D-NC), and Barney Frank (D-MA). Among other things, it would have expanded the scope of HOEPA to cover purchase money loans and open-end loans, and set the APR threshold at 5 percent. 
4012 CFR Parts 7 and 34, [Docket No. 04-04], RIN 1557-AC73, February 12, 2004.

41 Many observers and many of the U.S. financial regulatory system's leaders have described it as excessively complex and fragmented. A working group headed by the Secretary of the Treasury has called for the system's restructuring and simplification. A 
General Accounting Office 2004 report called for simplification (GAO 2004b). Major deregulation of the financial industry started with the Depository Institutions Deregulation and Monetary Control Act Of 1980 (DIDMCA). Among other things, DIDMCA eliminated controls over depository interest rates, pre-empted state usury 
limits on mortgage interest rates, and eliminated most restrictions on the lending products that banks could offer.

42 Wall Street Journal, March, 2007. 
43 Sarbanes- Oxley Act of 2002, Pub. L. No. 107-204, § 702(b), 116 Stat. 745 (2002).

$44 \quad$ www.iosco.org

Page 99 
45 See www. frb.com for the U.S. mplementation schedule, www. bis.org for the overall schedule and for separate countries' decisions regarding their implementation.

46 See Engel and McCoy (2007), as cited above.

Page 100 
47 Or, at least five years of performance data, per Basel II. This is unlikely to span a full real estate credit cycle. For example, the subprime boom period extended from 2000 to 2006, and the bust period has just begun. After its 1980 s real estate boom, the bottom 
of the cycle in Japan lasted more than ten years, referred to by some observers as the lost decade.

48 REF A2F sources, Jayamaha; Caskey, et al 2006.

Page 102 
49 Source: Author interviews with Titularizadora Colombiana.

50 Source: Author interviews with Sociedad Hipotecaria Federal.

51 In the case of Mexico and Peru, this refers to loans without inflation indexing.

Page 103 
52 Monthly housing payment includes principal, interest, taxes, and insurance. Total monthly obligations are defined as monthly housing payment plus other recurring debt obligations. 
53 See comments by consumer advocates and lenders to the 2006 Interagency Guidance on Nontraditional lending at www.occ.gov or www.federalreserve.gov.

54 Sources: SHF, interviews with lenders. 
55 For example: Germany, I reland, Netherlands, Sweden. and Australia.

56 IMF (2006).

57 http://www.reic.or.th/home_eng/home/default.asp 
58 For instance, Malaysia, France, and the United States.

59 For example, Mexico, Colombia, Peru, and the U.S.

Page 107 
60 For example, Fitch's Peru's office relies on staff from its office in Chile. Mainland China has not yet licensed any of the three major CRAs to operate.

61 For a mo re extensive discussion of consumer protection issues see Chapter 6 in Chiquier and Lea, 2008.

Page 108 
62 For an overview of behavioral economics, see Camerer, 2003.

63 Inflation-indexed mortgages have been prominent at different times in a number of countries, including Israel, Poland, Chile, Argentina, and Mexico. As inflation has fallen in 
recent years, shorter maturity fixed nominal rate loans have become popular in Colombia and Mexico. 